Submitted to Journal of Catalysis, August 14, 2015, revised December 7, 2015.

\title{
Highly-Active Nickel Phosphide Hydrotreating Catalysts Prepared In Situ Using Nickel Hypophosphite Precursors
}

\author{
Andrea I. d'Aquino, ${ }^{1,2}$ Samuel J. Danforth, ${ }^{1,2}$ Tess R. Clinkingbeard, ${ }^{1,2}$ Boris Ilic, ${ }^{1,2}$ \\ Lee Pullan, ${ }^{3}$ Michael A. Reynolds, ${ }^{4}$ Brendan D. Murray ${ }^{4}$ and Mark E. Bussell ${ }^{1,2} *$ \\ ${ }^{1}$ Department of Chemistry, MS-9150 \\ Western Washington University \\ Bellingham, WA 98225 \\ ${ }^{2}$ Advanced Materials Science and Engineering Center \\ Western Washington University \\ Bellingham, WA 98225 \\ ${ }^{3}$ FEI Company \\ 5350 NE Dawson Creek Dr. \\ Hillsboro, OR 97124 \\ ${ }^{4}$ Shell Oil Company \\ Westhollow Technology Center \\ 3333 Highway 6 South \\ Houston, TX 77082
}

*Author to whom correspondence should be addressed.

Correspondence Address

Prof. Mark E. Bussell

Department of Chemistry, MS-9150

Western Washington University

516 High Street

Bellingham, WA 98225

Tel: $360-650-3145$

Fax: 360-650-2826

E-mail: Mark.Bussell@wwu.edu 


\section{ABSTRACT}

An in situ method for the preparation of nickel phosphide $\left(\mathrm{Ni}_{2} \mathrm{P}\right)$ on silica, alumina, and amorphous silica-alumina (ASA) supports is described. The synthesis avoids the use of nickel and phosphorus salts by employing the reaction between nickel hydroxide $\left(\mathrm{Ni}(\mathrm{OH})_{2}\right)$ and hyphosphorus acid $\left(\mathrm{H}_{3} \mathrm{PO}_{2}\right)$, allowing the impregnation of nickel hypophosphite $\left(\mathrm{Ni}\left(\mathrm{H}_{2} \mathrm{PO}_{2}\right)_{2}\right)$ onto the oxide supports in the absence of salt byproducts. Temperature-programmed reduction (TPR) in flowing hydrogen at $573-773 \mathrm{~K}$ yields phase pure $\mathrm{Ni}_{2} \mathrm{P}$ on the supports with small average particle sizes (3-4 nm) as measured using transmission electron microscopy. The conversion of $\mathrm{Ni}\left(\mathrm{H}_{2} \mathrm{PO}_{2}\right)_{2}$ to $\mathrm{Ni}_{2} \mathrm{P}$ and related reactions were probed using TPR with on-line mass spectral analysis of the gas effluent. Unsupported $\mathrm{Ni}\left(\mathrm{H}_{2} \mathrm{PO}_{2}\right)_{2}$ reacts in flowing hydrogen to produce $\mathrm{PH}_{3}$ and $\mathrm{H}_{2} \mathrm{O}$ at 468 and $482 \mathrm{~K}$, respectively; the reaction is shifted to increasingly higher temperatures for $\mathrm{Ni}\left(\mathrm{H}_{2} \mathrm{PO}_{2}\right)_{2}$ supported on $\mathrm{SiO}_{2}, \mathrm{Al}_{2} \mathrm{O}_{3}$ and $\mathrm{ASA}$. The hydrodenitrogenation (HDN) and hydrodesulfurization (HDS) properties of the $\mathrm{Ni}_{2} \mathrm{P}$ catalysts were probed using a mixed feed containing carbazole and benzothiophene. While $\mathrm{Ni}_{2} \mathrm{P} / \mathrm{SiO}_{2}$ catalysts prepared by the different methods exhibited similar HDN and HDS activities, the in situ prepared $\mathrm{Ni}_{2} \mathrm{P} / \mathrm{Al}_{2} \mathrm{O}_{3}$ and $\mathrm{Ni}_{2} \mathrm{P} / \mathrm{ASA}$ catalysts were substantially more active than their ex situ counterparts prepared from hypophosphite- and phosphate-based precursors.

\section{KEYWORDS}

Hydrodenitrogenation, carbazole, hydrodesulfurization, benzothiophene, nickel phosphide, nickel hypophosphite 


\section{INTRODUCTION}

Recent research aimed at the improvement of hydrotreating catalysts has concentrated on the optimization of sulfide-based materials as well as step-out investigations of new classes of materials, many of which have focused on metal phosphides. A growing body of research on the hydrotreating properties of metal phosphides indicates nickel phosphide $\left(\mathrm{Ni}_{2} \mathrm{P}\right)$ to be the most promising candidate for a new generation of hydrodesulfurization (HDS) and hydrodenitrogenation (HDN) catalysts [1,2]. A recent study showed $\mathrm{Ni}_{2} \mathrm{P} / \mathrm{SiO}_{2}$ to be more active (on a mass basis) than a commercial $\mathrm{Ni}-\mathrm{Mo} / \mathrm{Al}_{2} \mathrm{O}_{3}$ catalyst for the $\mathrm{HDN}$ of carbazole, but the $\mathrm{Ni}_{2} \mathrm{P}$ catalyst had a lower turnover frequency (TOF) than did the Ni-Mo sulfide catalyst [3]. More recently, an investigation of unsupported $\mathrm{Ni}_{2} \mathrm{P}$-based catalysts showed HDS of a mixed feed to scale with surface area for materials having surface areas in the range $14-45 \mathrm{~m}^{2} / \mathrm{g}$ [4]. Not surprisingly given the low surface area of the materials, the $\mathrm{Ni}_{2} \mathrm{P}$-based catalysts were substantially less active than a state-of-the-art Co-Mo/ $/ \mathrm{Al}_{2} \mathrm{O}_{3}$ catalyst. Based on an extrapolation of the activities of $\mathrm{Ni}_{2} \mathrm{P}$-based catalysts to that of the $\mathrm{Co}-\mathrm{Mo} / \mathrm{Al}_{2} \mathrm{O}_{3}$ catalyst, the authors concluded that unsupported $\mathrm{Ni}_{2} \mathrm{P}$ would need to have a surface area of $\sim 400 \mathrm{~m}^{2} / \mathrm{g}$ (or a particle size of $\sim 3 \mathrm{~nm}$ ) to be comparable in activity to a state-of-the art Co-Mo catalyst [4].

Nickel phosphide catalysts are most often prepared by temperature-programmed reduction (TPR) of precursors prepared by impregnation of aqueous nickel and phosphorus salts (e.g. nickel nitrate and ammonium dihydrogen phosphate) onto an oxide support followed by drying and calcination in air. When supported on silica, a maximum TPR temperature of $873 \mathrm{~K}$ or higher is typically needed to reduce the precursor to $\mathrm{Ni}_{2} \mathrm{P}$ [2,5]. In addition, an excess of $\mathrm{P}$ in the precursor $(\mathrm{P} / \mathrm{Ni}$ molar ratio $>0.50)$ is needed to ensure that phase pure $\mathrm{Ni}_{2} \mathrm{P}$ is formed on the silica support. Due to the strong interaction of impregnated phosphate with Al-containing supports (leading to formation of $\mathrm{AlPO}_{4}$ upon calcination), higher reduction temperatures and $\mathrm{P}$ contents in the 
precursors are needed to produce $\mathrm{Ni}_{2} \mathrm{P}$ [5]. In the last few years, new synthetic approaches that use phosphite $\left(\mathrm{H}_{2} \mathrm{PO}_{3}^{-}\right)$or hypophosphite $\left(\mathrm{H}_{2} \mathrm{PO}_{2}^{-}\right)$in place of phosphate $\left(\mathrm{PO}_{4}{ }^{3-}\right)$ as the $\mathrm{P}$ source have been reported that enable the preparation of $\mathrm{Ni}_{2} \mathrm{P}$ and other metal phosphides at substantially lower temperatures [2,6-11]. The lower oxidation state of phosphorus in hypophosphite $(\mathrm{P}+1)$ and phosphite $(\mathrm{P}+3)$ than in phosphate $(\mathrm{P}+5)$ allows reduction of the precursors at lower temperatures than is possible for phosphate-based precursors [2]. The lower reduction temperatures used to prepare $\mathrm{Ni}_{2} \mathrm{P}$ catalysts from hypophosphite- and phosphite-based precursors have resulted in smaller particle sizes and higher HDS activities in comparison with $\mathrm{Ni}_{2} \mathrm{P}$ catalysts prepared from phosphatebased precursors.

In addition to yielding small particles, an industrially viable synthesis for $\mathrm{Ni}_{2} \mathrm{P}$ catalysts should involve as few steps as possible and a reduction temperature that does not exceed the maximum operating temperature of the reactor vessel. Ideally, the $\mathrm{Ni}_{2} \mathrm{P}$ catalyst would be prepared in situ and at a temperature of $673 \mathrm{~K}$ or lower and the synthesis method should work equally well for aluminum-containing supports as it does for silica. Herein we report a new in situ preparation method that yields highly active $\mathrm{Ni}_{2} \mathrm{P}$ catalysts supported on $\mathrm{SiO}_{2}, \gamma-\mathrm{Al}_{2} \mathrm{O}_{3}$ and amorphous $\mathrm{SiO}_{2}-$ $\mathrm{Al}_{2} \mathrm{O}_{3}$ (ASA).

\section{EXPERIMENTAL METHODS}

\subsection{Catalyst Synthesis}

The precursors of the nickel phosphide catalysts were prepared by impregnation of aqueous solutions of either nickel hypophosphite or phosphate onto calcined supports followed by drying. Three different oxide supports were used: $\mathrm{SiO}_{2}$ (Cab-O-Sil, EH-5, $380 \mathrm{~m}^{2} / \mathrm{g}$ ), $\gamma-\mathrm{Al}_{2} \mathrm{O}_{3}$ (Engelhard, AL-3945, $186 \mathrm{~m}^{2} / \mathrm{g}$ ) and ASA (Criterion, 5545, $412 \mathrm{~m}^{2} / \mathrm{g}$ ), and were calcined at $773 \mathrm{~K}$ in air for $3 \mathrm{~h}$. The reagents used in the catalyst synthesis were nickel hydroxide $\left(\mathrm{Ni}(\mathrm{OH})_{2}\right.$, Alfa Aesar, $\left.61 \% \mathrm{Ni}\right)$, 
$\mathrm{Ni}\left(\mathrm{NO}_{3}\right)_{2} \bullet 6 \mathrm{H}_{2} \mathrm{O}$ (Alfa Aesar, Puratronic, 99.9985\%), hypophosphorous acid $\left(\mathrm{H}_{3} \mathrm{PO}_{2}\right.$, Sigma-

Aldrich, 50 wt $\%$ in $\left.\mathrm{H}_{2} \mathrm{O}\right)$ and ammonium dihydrogen phosphate $\left(\mathrm{NH}_{4} \mathrm{H}_{2} \mathrm{PO}_{4}\right.$, Alfa Aesar, ACS grade). The nominal loadings of the catalysts prepared were $15 \mathrm{wt} \% \mathrm{Ni}_{2} \mathrm{P} / \mathrm{SiO}_{2}, 25 \mathrm{wt} \%$ $52 \quad \mathrm{Ni}_{2} \mathrm{P} / \mathrm{Al}_{2} \mathrm{O}_{3}$, and $25 \mathrm{wt} \% \mathrm{Ni}_{2} \mathrm{P} / \mathrm{ASA}$.

\subsection{1 $\mathrm{Ni}_{2} \mathrm{P}$ Catalysts Prepared Using Hypophosphite}

The impregnation solutions for the hypophosphite-based precursors were prepared by adding a stoichiometric amount of $50 \mathrm{wt} \% \mathrm{H}_{3} \mathrm{PO}_{2}(\mathrm{aq})$ to powdered $\mathrm{Ni}(\mathrm{OH})_{2}$ with stirring, yielding a light green mixture having a phosphorus-to-nickel mole ratio $(\mathrm{P} / \mathrm{Ni})=2$. The mixture was then heated to $343 \mathrm{~K}$ and water was added as needed to form a clear, green solution of $\mathrm{Ni}\left(\mathrm{H}_{2} \mathrm{PO}_{2}\right)_{2}(\mathrm{aq})$. This solution was directly impregnated onto the $\mathrm{SiO}_{2}, \gamma-\mathrm{Al}_{2} \mathrm{O}_{3}$, and ASA supports until incipient wetness to give precursors having $\mathrm{P} / \mathrm{Ni}=2.0$. An additional $\mathrm{Ni}_{2} \mathrm{P} / \mathrm{SiO}_{2}$ catalyst having $\mathrm{P} / \mathrm{Ni}=1.5$ was prepared; in this case enough $\mathrm{Ni}\left(\mathrm{NO}_{3}\right)_{2} \bullet 6 \mathrm{H}_{2} \mathrm{O}$ was added to the impregnation solution to adjust the $\mathrm{P} / \mathrm{Ni}$ molar ratio to 1.5 prior to the first impregnation. The HDN/HDS testing for $\mathrm{Ni}_{2} \mathrm{P} / \mathrm{SiO}_{2}$ was carried out using the precursor having $\mathrm{P} / \mathrm{Ni}=1.5$ as this catalyst had a significantly higher activity than the catalyst prepared from a precursor having $\mathrm{P} / \mathrm{Ni}=2.0$. If more than one impregnation was necessary to prepare a precursor, the solution was held at $343 \mathrm{~K}$ between impregnations. As an example, the precursor of a $15 \mathrm{wt} \% \mathrm{Ni}_{2} \mathrm{P} / \mathrm{SiO}_{2}$ catalyst having $\mathrm{P} / \mathrm{Ni}=1.5$ was prepared by impregnation of a solution containing $0.2812 \mathrm{~g} \mathrm{Ni}(\mathrm{OH})_{2}, 0.885 \mathrm{~mL} \mathrm{H}_{3} \mathrm{PO}_{2}$ and $0.2940 \mathrm{~g}$ $\mathrm{Ni}\left(\mathrm{NO}_{3}\right)_{2} \cdot 6 \mathrm{H}_{2} \mathrm{O}$ onto $1.7 \mathrm{~g} \mathrm{SiO}_{2}$, followed by drying at $343 \mathrm{~K}$ for $24 \mathrm{~h}$.

The supported $\mathrm{Ni}\left(\mathrm{H}_{2} \mathrm{PO}_{2}\right)_{2} \cdot 6 \mathrm{H}_{2} \mathrm{O}$ precursors were reduced via temperature-programmed reduction (TPR) as follows. Approximately $0.5 \mathrm{~g}$ of the precursor was transferred to a quartz $\mathrm{U}$ tube and degassed in $60 \mathrm{~mL} / \mathrm{min} \mathrm{He}$ (Airgas, 99.999\%) for $30 \mathrm{~min}$. The precursor was then subjected to TPR in $\mathrm{H}_{2}$ (Airgas, 99.999\%) flowed at $100 \mathrm{~mL} / \mathrm{min}$ by heating from room temperature at a heating rate of $5 \mathrm{~K} / \mathrm{min}$ to a temperature in the range 573-773 $\mathrm{K}$. After holding for $1 \mathrm{~h}$, the 
resulting $\mathrm{Ni}_{2} \mathrm{P}$ catalyst was cooled to room temperature in continued $\mathrm{H}_{2}$ flow, purged for 30 min in $60 \mathrm{~mL} / \mathrm{min} \mathrm{He}$, and then passivated in $60 \mathrm{~mL} / \mathrm{min} 1 \mathrm{~mol} \% \mathrm{O}_{2} / \mathrm{He}$ (Airgas, 99\%) for $2 \mathrm{~h}$. The in situ preparation of the supported $\mathrm{Ni}_{2} \mathrm{P}$ catalysts is described in Sections 2.2-2.4. The $\mathrm{Ni}_{2} \mathrm{P}$ loadings (15 wt\% $\left.\left(\mathrm{SiO}_{2}\right), 25 \mathrm{wt} \%\left(\mathrm{Al}_{2} \mathrm{O}_{3}, \mathrm{ASA}\right)\right)$ were selected in order to give catalysts with similar $\mathrm{Ni}_{2} \mathrm{P}$ particle sizes (3-4 $\mathrm{nm}$, as determined by TEM).

\subsection{2 $\mathrm{Ni}_{2} \mathrm{P}$ Catalysts Prepared Using Phosphate}

The impregnation solutions for phosphate-based precursors were prepared by dissolving $\mathrm{Ni}\left(\mathrm{NO}_{3}\right)_{2} \cdot 6 \mathrm{H}_{2} \mathrm{O}$ and $\mathrm{NH}_{4} \mathrm{H}_{2} \mathrm{PO}_{4}$ in water, and has been described in detail elsewhere [3]. The composition of the impregnation solution depended upon the support used: $\mathrm{SiO}_{2}(\mathrm{P} / \mathrm{Ni}=0.9), \gamma$ $\mathrm{Al}_{2} \mathrm{O}_{3}(\mathrm{P} / \mathrm{Ni}=1.5), \mathrm{ASA}(\mathrm{P} / \mathrm{Ni}=2.2)$. The solution was impregnated onto the support until incipient wetness; if more than one impregnation was necessary, the solid was dried at $393 \mathrm{~K}$ between impregnations. After the final solution addition, the catalyst precursor was dried for $24 \mathrm{~h}$ at $393 \mathrm{~K}$. Approximately $0.5 \mathrm{~g}$ of the precursor was transferred to a quartz U-tube and degassed in $60 \mathrm{~mL} / \mathrm{min}$ He for 30 min. The precursor was then subjected to TPR in $\mathrm{H}_{2}$ flowed at $150 \mathrm{~mL} / \mathrm{min}$ by heating from room temperature to $923 \mathrm{~K}$ at a heating rate of $1 \mathrm{~K} / \mathrm{min}$. Following TPR, the $\mathrm{Ni}_{2} \mathrm{P}$ catalyst was cooled to room temperature in continued $\mathrm{H}_{2}$ flow, purged for $30 \mathrm{~min}$ in $60 \mathrm{~mL} / \mathrm{min} \mathrm{He}$, and then passivated in $60 \mathrm{~mL} / \mathrm{min} 1 \mathrm{~mol} \% \mathrm{O}_{2} / \mathrm{He}$ (Airgas, 99\%) for $2 \mathrm{~h}$. The P/Ni molar ratios used corresponded to the amounts needed to achieve phase-pure $\mathrm{Ni}_{2} \mathrm{P}$ on each support.

\subsection{Catalyst Characterization}

Powder X-ray diffraction patterns of the supported $\mathrm{Ni}_{2} \mathrm{P}$ catalysts were obtained using a PANalytical X'Pert Pro diffractometer equipped with a monochromatic $\mathrm{Cu}-\mathrm{K} \alpha$ source $(\lambda=1.54050$ Å). A Micromeritics AutoChem 2950HP instrument outfitted with a thermal conductivity detector was used to carry out carbon monoxide (CO) chemisorption capacity and single-point BET surface area measurements for the catalysts. Approximately $0.050 \mathrm{~g}$ of a catalyst precursor or passivated 
catalyst was placed in a metal U-tube that was then attached to the instrument. Following degassing in $60 \mathrm{~mL} / \mathrm{min} \mathrm{He}$ for $30 \mathrm{~min}$, the sample was heated to $673 \mathrm{~K}$ at $10 \mathrm{~K} / \mathrm{min}$ in $60 \mathrm{~mL} / \mathrm{min} \mathrm{H}_{2}$ and held for $1 \mathrm{~h}$ in continued $\mathrm{H}_{2}$ flow. The sample was then purged in $60 \mathrm{~mL} / \mathrm{min} \mathrm{He}$ for $1 \mathrm{~h}$ at $673 \mathrm{~K}$, and subsequently cooled to room temperature in continued He flow. With the sample held at $273 \mathrm{~K}$, $10 \mathrm{~mol} \% \mathrm{CO} / \mathrm{He}$ (Praxair) was pulsed over the sample until $\mathrm{CO}$ uptake ceased. The $\mathrm{CO}$ was desorbed from the catalyst sample by heating to $623 \mathrm{~K}$, after which a single-point BET measurement was carried out at $77 \mathrm{~K}$ using $30.03 \mathrm{~mol} \% \mathrm{~N}_{2} / \mathrm{He}$.

Transmission electron microscopy (TEM) measurements were carried out using a FEI Talos F200X high resolution transmission electron microscope operating at $200 \mathrm{keV}$ and outfitted with a FEI Super-X energy dispersive X-ray (EDX) analysis system. Catalyst samples were placed on a 200 mesh copper grid coated with formvar and carbon for the TEM measurements.

X-ray photoelectron spectroscopy (XPS) spectra were acquired of the hypophosphite-based precursors and the supported $\mathrm{Ni}_{2} \mathrm{P}$ catalysts prepared ex situ using a SAGE 100 XPS System (SPECS GmbH) outfitted with a $\mathrm{Mg} \mathrm{K} \alpha$ X-ray source $(1253.6 \mathrm{eV})$ and a $95 \mathrm{~mm}$ hemispherical energy analyzer. XPS spectra of the catalysts after HDN/HDS testing were acquired using a Thermo Scientific K-Alpha XPS system outfitted with a Mg Ka X-ray source (1253.6 eV) and a $180^{\circ}$ double focusing hemispherical analyser-128-channel detector. The XPS spectra were collected with a pass energy of 15 or $50 \mathrm{eV}$ and binding energies were corrected for sample charging using the $\mathrm{C}(1 \mathrm{~s})$ peak at $284.6 \mathrm{eV}$ for adventitious carbon as a reference. Surface compositions were determined for the $\mathrm{Ni}_{2} \mathrm{P}$ catalysts using the peak areas in the $\mathrm{Ni}(2 \mathrm{p})$ and $\mathrm{P}(2 \mathrm{p})$ regions and the instrument relative sensitivity factors.

\subsection{Temperature-Programmed Reduction - Mass Spectrometry}

Temperature-programmed reduction - mass spectrometry (TPR-MS) measurements were carried out using a Micromeritics Autochem 2950HP instrument outfitted with a MKS Cirrus 2 
mass spectrometer for on-line detection of the gas-phase effluent. Approximately $0.05 \mathrm{~g}$ of catalyst precursor (or reference material) was loaded into a metal U-tube and attached to the instrument. Following degassing in $60 \mathrm{~mL} / \mathrm{min}$ He for $60 \mathrm{~min}$, the sample was heated from 300 to $1023 \mathrm{~K}$ at 10 $\mathrm{K} / \mathrm{min}$ in $50 \mathrm{~mL} / \mathrm{min} 10 \mathrm{~mol} \% \mathrm{H}_{2} / \mathrm{Ar}$ (Praxair) while monitoring mass-to-charge ratios (m/z) of 18 $\left(\mathrm{H}_{2} \mathrm{O}\right), 31(\mathrm{P})$ and $34\left(\mathrm{PH}_{3}\right)$. The mass spectrometer has a temperature calibration that interfaces with the AutoChem 2950 thermocouple signal; this calibration is in good agreement with peak temperatures in the TCD signal, which come directly from thermocouple measurement. There is a 1-2 s delay in the MS signal due to gases entering the capillary to the mass spectrometer, but this corresponds to a temperature offset of $<2 \mathrm{~K}$. Sodium hypophosphite $\left(\mathrm{NaH}_{2} \mathrm{PO}_{2}\right.$, Sigma-Aldrich, >99\%) was used as a reference compound for TPR-MS measurements.

\subsection{HDN and HDS activity measurements}

Carbazole HDN and benzothiophene HDS activity measurements were carried out using a fixed-bed, continuous flow reactor operating at a total pressure of 3.0 $\mathrm{MPa}$ and temperatures in the range of 548-673 K. The reactor feed consisted of $3000 \mathrm{ppm}$ benzothiophene, 1000 ppm carbazole, and $500 \mathrm{ppm}$ dodecane in a $39.55 \mathrm{wt} \% \mathrm{p}$-xylene/decane solution. The $500 \mathrm{ppm}$ dodecane served as an internal standard for the gas chromatographic analysis of the reactor effluent. The liquid feed $(5.4 \mathrm{~mL} / \mathrm{h})$ was injected into a $50 \mathrm{~mL} / \mathrm{min}$ flow of hydrogen, where it was preheated and vaporized prior to entry into the reactor. A sample (0.25 g, 16-20 mesh size) of catalyst precursor or passivated catalyst was diluted with quartz flakes to a total volume of $5 \mathrm{~mL}$ and loaded into a reactor tube having a diameter of $1.1 \mathrm{~cm}$ and length of $40 \mathrm{~cm}$. The internal reactor temperature was monitored with an axially mounted thermocouple in direct contact with the catalyst bed. The catalyst precursors or passivated catalysts were pretreated by heating from room temperature to 673 $\mathrm{K}$ in $1 \mathrm{~h}$ in a $60 \mathrm{~mL} / \mathrm{min}$ flow of $\mathrm{H}_{2}$ and were held at this temperature for $2 \mathrm{~h}$, then cooled to room temperature in continued $\mathrm{H}_{2}$ flow. In one experiment, the hypophosphite-based precursor of a 
$145 \mathrm{Ni}_{2} \mathrm{P} / \mathrm{SiO}_{2}$ catalyst was subjected to a sulfidation pretreatment by heating from room temperature to $146650 \mathrm{~K}$ in $1 \mathrm{~h}$ in a $60 \mathrm{~mL} / \mathrm{min}$ flow of $3 \mathrm{~mol} \% \mathrm{H}_{2} \mathrm{~S} / \mathrm{H}_{2}$, held at this temperature for $2 \mathrm{~h}$, and then 147 cooled to room temperature in continued $\mathrm{H}_{2} \mathrm{~S} / \mathrm{H}_{2}$ flow.

148 Following the pretreatment and cooling to room temperature, the reactor was pressurized to $1493.0 \mathrm{MPa}$ with $\mathrm{H}_{2}$. In a $50 \mathrm{~mL} / \mathrm{min}$ flow of $\mathrm{H}_{2}$, the catalyst bed was heated to $548 \mathrm{~K}$ and the flow of 150 liquid feed was begun. The reactor was allowed to stabilize under operating conditions for $3 \mathrm{~h}$ prior intervals. This procedure was repeated until sampling at the maximum catalyst temperature $(673 \mathrm{~K})$ was completed. The first effluent sample collected at each temperature was discarded, while the four subsequent effluent samples were analyzed off-line using a gas chromatograph (Agilent $6890 \mathrm{~N}$ ) equipped with an HP-5 column and a flame ionization detector. The GC was calibrated using serial diluted product standard solutions to allow product quantification of reactor effluent samples. Based on this method carbon balances of $\sim 95 \%$ were achieved, indicating that the analyses of the reactor effluent accounted for all of the major reaction products. The majority of the HDN and HDS activity measurements were done in duplicate to ensure reproducibility.

\section{RESULTS}

\subsection{Catalyst Synthesis and TPR-MS Measurements}

Mixing stoichiometric amounts $(\mathrm{P} / \mathrm{Ni}=2)$ of $\mathrm{Ni}(\mathrm{OH})_{2}(\mathrm{~s})$ and $\mathrm{H}_{3} \mathrm{PO}_{2}(\mathrm{aq})$ resulted in the formation of a greenish solution containing some undissolved $\mathrm{Ni}(\mathrm{OH})_{2}(\mathrm{~s})$. Heating this mixture to $343 \mathrm{~K}$ led to complete dissolution of the remaining $\mathrm{Ni}(\mathrm{OH})_{2}(\mathrm{~s})$ and the formation of a clear, green solution. Upon cooling to room temperature, green crystals precipitated from solution that were previously identified as $\mathrm{Ni}\left(\mathrm{H}_{2} \mathrm{PO}_{2}\right)_{2} \bullet 6 \mathrm{H}_{2} \mathrm{O}(\mathrm{s})$ [12-14]. The $\mathrm{Ni}\left(\mathrm{H}_{2} \mathrm{PO}_{2}\right)_{2} \bullet 6 \mathrm{H}_{2} \mathrm{O}(\mathrm{s})$ fully redissolved 
169 upon heating to $343 \mathrm{~K}$ to give an approximately $1.2 \mathrm{M} \mathrm{Ni}\left(\mathrm{H}_{2} \mathrm{PO}_{2}\right)_{2}(\mathrm{aq})$ solution (see Supplementary

170 Material). The $\mathrm{Ni}\left(\mathrm{H}_{2} \mathrm{PO}_{2}\right)_{2} \bullet 6 \mathrm{H}_{2} \mathrm{O}(\mathrm{aq})$ solution was maintained at $343 \mathrm{~K}$ between impregnations of

171 the $\mathrm{SiO}_{2}, \gamma-\mathrm{Al}_{2} \mathrm{O}_{3}$ and ASA supports to keep the nickel hypophosphite fully dissolved. Heating the

$172 \mathrm{Ni}\left(\mathrm{H}_{2} \mathrm{PO}_{2}\right)_{2} \bullet 6 \mathrm{H}_{2} \mathrm{O}(\mathrm{s}), \mathrm{Ni}\left(\mathrm{H}_{2} \mathrm{PO}_{2}\right)_{2} \bullet 6 \mathrm{H}_{2} \mathrm{O}(\mathrm{aq})$ or impregnated supports to higher drying temperatures

173 in air (e.g. $393 \mathrm{~K}$ ) resulted in decomposition of the nickel hypophosphite within $24 \mathrm{~h}$ (see

174 Supplementary Material).

175 The reactions of unsupported and oxide-supported $\mathrm{Ni}\left(\mathrm{H}_{2} \mathrm{PO}_{2}\right)_{2} \bullet 6 \mathrm{H}_{2} \mathrm{O}$, as well as of

176 unsupported $\mathrm{NaH}_{2} \mathrm{PO}_{2}$, were investigated using TPR-MS. Shown in Figure 1 are TPR-MS traces

177 for water $(\mathrm{m} / \mathrm{z}=18)$ and phosphine $(\mathrm{m} / \mathrm{z}=34)$ for unsupported $\mathrm{NaH}_{2} \mathrm{PO}_{2}$ in $\mathrm{Ar}$ and $10 \mathrm{~mol} \% \mathrm{H}_{2} / \mathrm{Ar}$

178 over the temperature range $300-1023 \mathrm{~K}$. The decomposition of $\mathrm{NaH}_{2} \mathrm{PO}_{2}$ in argon shows a large

179 phosphine $\left(\mathrm{PH}_{3}\right)$ peak centered at $535 \mathrm{~K}$ and a smaller second peak at $579 \mathrm{~K}$. Only a small amount

180 of water is produced, with a very weak peak at $536 \mathrm{~K}$ and a somewhat larger peak at $575 \mathrm{~K}$.

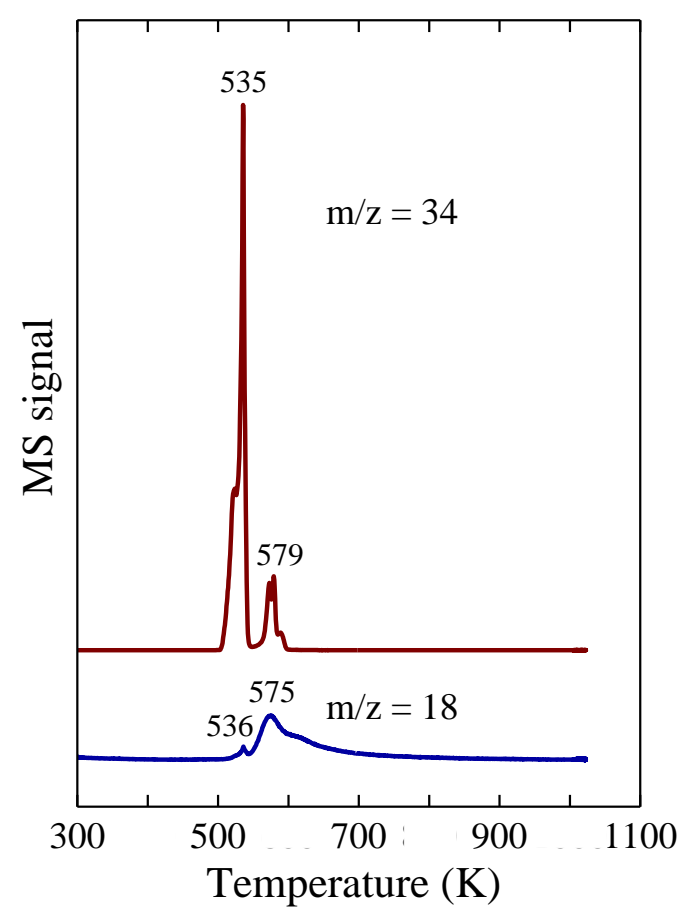

(a)

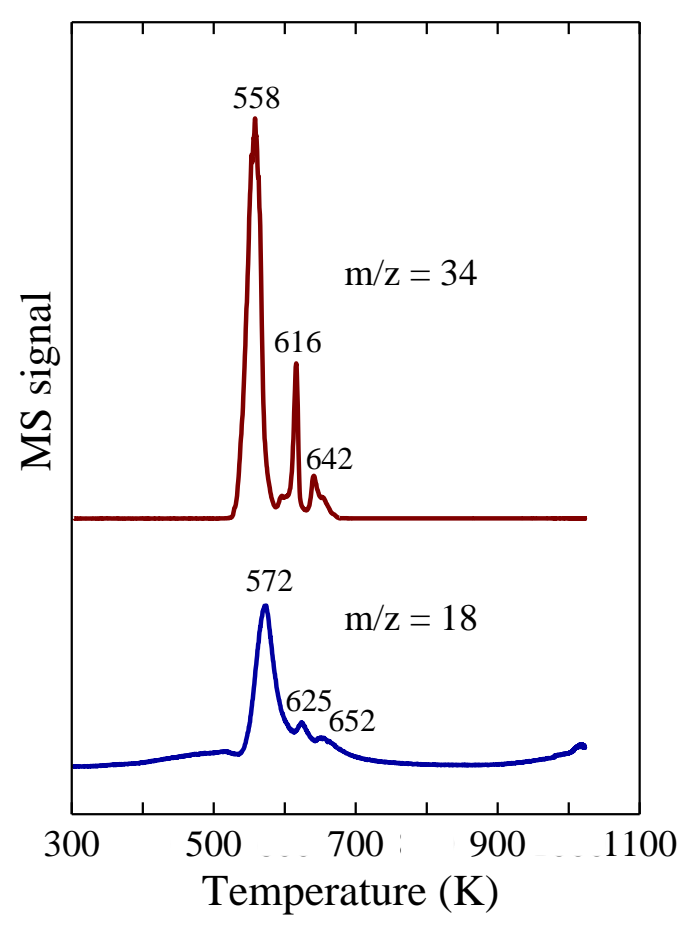

(b)

Figure 1: TPR-MS traces for $\mathrm{NaH}_{2} \mathrm{PO}_{2}$ in (a) Ar and (b) $10 \% \mathrm{H}_{2} / \mathrm{Ar}$. 
183 Drawing upon thermal gravimetric analysis (TGA) results reported by others [15], the following reactions are proposed for the two-step decomposition of $\mathrm{NaH}_{2} \mathrm{PO}_{2}$ in flowing Ar.

$$
\begin{array}{r}
5 \mathrm{NaH}_{2} \mathrm{PO}_{2} \rightarrow 2 \mathrm{PH}_{3}+2 \mathrm{Na}_{2} \mathrm{HPO}_{3}+\mathrm{NaH}_{2} \mathrm{PO}_{4} \\
8 \mathrm{Na}_{2} \mathrm{HPO}_{3} \rightarrow 2 \mathrm{PH}_{3}+4 \mathrm{Na}_{3} \mathrm{PO}_{4}+\mathrm{Na}_{4} \mathrm{P}_{2} \mathrm{O}_{7}+\mathrm{H}_{2} \mathrm{O}
\end{array}
$$

The observation of $\mathrm{PH}_{3}$ in the TPR-MS trace at $535 \mathrm{~K}$ is assigned to the reaction shown in Equation 1 that involves the disproportionation of $\mathrm{NaH}_{2} \mathrm{PO}_{2}$ to give $\mathrm{PH}_{3}$, disodium hydrogen phosphite $\left(\mathrm{Na}_{2} \mathrm{HPO}_{3}\right)$ and sodium dihydrogen phosphate $\left(\mathrm{NaH}_{2} \mathrm{PO}_{4}\right)$, but not water. The observation of $\mathrm{PH}_{3}$ and water at 579 and $575 \mathrm{~K}$, respectively, is assigned to the subsequent reaction of the $\mathrm{Na}_{2} \mathrm{HPO}_{3}$ as shown in Equation 2. Sodium phosphate $\left(\mathrm{Na}_{3} \mathrm{PO}_{4}\right)$ and sodium pyrophosphate $\left(\mathrm{Na}_{4} \mathrm{P}_{2} \mathrm{O}_{7}\right)$ remain as solid residue upon further heating in Ar flow. The reaction of $\mathrm{NaH}_{2} \mathrm{PO}_{2}$ in $10 \mathrm{~mol} \% \mathrm{H}_{2} / \mathrm{Ar}$ exhibits a different TPR-MS trace, with the first $\mathrm{PH}_{3}$ peak shifted to $558 \mathrm{~K}$ as well as being accompanied by a $\mathrm{H}_{2} \mathrm{O}$ peak. It is unclear whether $\mathrm{H}_{2}$ directly participates in the reaction of the $\mathrm{NaH}_{2} \mathrm{PO}_{2}$ or simply leads to a different decomposition pathway resulting in simultaneous evolution of $\mathrm{PH}_{3}$ and $\mathrm{H}_{2} \mathrm{O}$; two possible

$$
\begin{gathered}
4 \mathrm{NaH}_{2} \mathrm{PO}_{2} \rightarrow 2 \mathrm{PH}_{3}+\mathrm{Na}_{4} \mathrm{P}_{2} \mathrm{O}_{7}+\mathrm{H}_{2} \mathrm{O} \\
14 \mathrm{NaH}_{2} \mathrm{PO}_{2} \rightarrow 6 \mathrm{PH}_{3}+4 \mathrm{Na}_{2} \mathrm{HPO}_{3}+2 \mathrm{NaPO}_{3}+\mathrm{Na}_{4} \mathrm{P}_{2} \mathrm{O}_{7}+3 \mathrm{H}_{2} \mathrm{O}
\end{gathered}
$$

reactions are depicted in Equations 3 [15] and 4.

The reaction shown in Equation 3 is unlikely to be operative in this case, as the remaining $\mathrm{P}$ species ( $\mathrm{Na}_{4} \mathrm{P}_{2} \mathrm{O}_{7}$ ) would not be expected to react with $\mathrm{H}_{2}$ until high temperatures so it is unclear what species would be reacting to produce $\mathrm{PH}_{3}$ and $\mathrm{H}_{2} \mathrm{O}$ in the 590-680 range. The reaction in Equation 4 seems more likely, as it produces $\mathrm{PH}_{3}$ and $\mathrm{H}_{2} \mathrm{O}$, but also $\mathrm{Na}_{2} \mathrm{HPO}_{3}$ that would be expected to 
204 subsequently decompose to form $\mathrm{PH}_{3}$ and $\mathrm{H}_{2} \mathrm{O}$ as shown in Equation 2. The $\mathrm{NaPO}_{3}$ that is formed 205 in Equation 4 exists as a hexamer species, sodium hexametaphosphate $\left(\left(\mathrm{NaPO}_{3}\right)_{6}\right)$, and is not 206 expected to undergo reaction until high temperature.

The replacement of sodium with nickel leads to a substantially different TPR-MS trace, as

208 shown in Figure 2 for the reaction of

$209 \mathrm{Ni}\left(\mathrm{H}_{2} \mathrm{PO}_{2}\right)_{2} \cdot 6 \mathrm{H}_{2} \mathrm{O}$ in 10

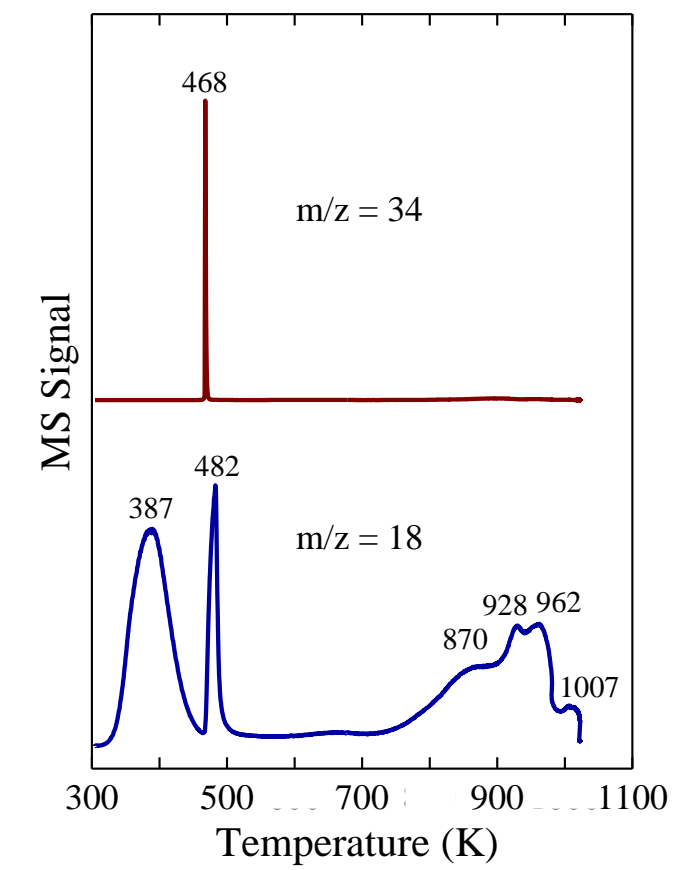
$\mathrm{mol} \% \mathrm{H}_{2} / \mathrm{Ar}$.

220 Reaction of the $\mathrm{Ni}\left(\mathrm{H}_{2} \mathrm{PO}_{2}\right)_{2} \cdot 6 \mathrm{H}_{2} \mathrm{O}$ was preceded by the removal of the waters of hydration in a 221 broad peak centered at $387 \mathrm{~K}$ in the $\mathrm{m} / \mathrm{z}=18$ trace. Evolution of $\mathrm{PH}_{3}$ occurred in a very sharp peak 222 at $468 \mathrm{~K}$ and of $\mathrm{H}_{2} \mathrm{O}$ at $482 \mathrm{~K}$, signaling the reaction of $\mathrm{Ni}\left(\mathrm{H}_{2} \mathrm{PO}_{2}\right)_{2}$ in $10 \mathrm{~mol} \% \mathrm{H}_{2} / \mathrm{Ar}$ flow at a 223 substantially lower temperature than was observed for $\mathrm{NaH}_{2} \mathrm{PO}_{2}$. No further reaction was observed 224 in the TPR-MS traces until the temperature is increased above $\sim 750 \mathrm{~K}$ with four overlapping $\mathrm{H}_{2} \mathrm{O}$ 225 peaks at 870, 928, 962 and $1007 \mathrm{~K}$; these peaks are presumed to be associated with the reaction of 226 phosphate species with $\mathrm{H}_{2}$. The observation of only a single, sharp $\mathrm{PH}_{3}$ evolution peak suggests a 
concerted process for the reaction of unsupported $\mathrm{Ni}\left(\mathrm{H}_{2} \mathrm{PO}_{2}\right)_{2}$ with $\mathrm{H}_{2}$ to form $\mathrm{Ni}_{2} \mathrm{P}$, as suggested below in Equation 5.

$$
\begin{gathered}
12 \mathrm{Ni}\left(\mathrm{H}_{2} \mathrm{PO}_{2}\right)_{2}+35 \mathrm{H}_{2} \rightarrow 6 \mathrm{Ni}_{2} \mathrm{P}+14 \mathrm{PH}_{3}+32 \mathrm{H}_{2} \mathrm{O}+4 \mathrm{H}_{3} \mathrm{PO}_{4} \\
6 \mathrm{Ni}\left(\mathrm{H}_{2} \mathrm{PO}_{2}\right)_{2}+5 \mathrm{H}_{2} \rightarrow 2 \mathrm{Ni}_{2} \mathrm{P}+2 \mathrm{Ni}\left(\mathrm{HPO}_{3} \mathrm{H}\right)_{2}+4 \mathrm{PH}_{3}+4 \mathrm{H}_{2} \mathrm{O}+2 \mathrm{H}_{3} \mathrm{PO}_{4}
\end{gathered}
$$

This reaction would account for the observed evolution of $\mathrm{PH}_{3}$ and $\mathrm{H}_{2} \mathrm{O}$ at 468 and $482 \mathrm{~K}$, respectively, and the subsequent hydrogenation of adsorbed $\mathrm{H}_{\mathrm{x}} \mathrm{PO}_{4}{ }^{(3-\mathrm{x})-}$ species above $750 \mathrm{~K}$. The reaction expressed in Equation 6, which is similar to one proposed elsewhere [16], seems unlikely as the subsequent reaction of $\mathrm{Ni}\left(\mathrm{HPO}_{3} \mathrm{H}\right)_{2}$ would be expected to be accompanied by the evolution of $\mathrm{PH}_{3}$ (and $\mathrm{H}_{2} \mathrm{O}$ ) in a peak at $\sim 773 \mathrm{~K}$ [7]. In a separate experiment, TPR was carried out for unsupported $\mathrm{Ni}\left(\mathrm{H}_{2} \mathrm{PO}_{2}\right)_{2}$ to $500 \mathrm{~K}$ (i.e. just beyond the $\mathrm{PH}_{3}$ and $\mathrm{H}_{2} \mathrm{O}$ evolution peaks) and the solid product was collected after passivation in $1 \mathrm{~mol} \% \mathrm{O}_{2} / \mathrm{He}$. A portion of the solid was rinsed with $\mathrm{H}_{2} \mathrm{O}$ and the solution was determined to be acidic (Figure S4c) and the IR spectrum of the viscous liquid residue collected after drying closely matches that of $\mathrm{H}_{3} \mathrm{PO}_{4}$ (Figure S5). An XRD pattern of the unwashed solid (Figure S6) exhibits strong peaks for $\mathrm{Ni}_{2} \mathrm{P}$ and weak peaks at 30.8, 48.2 and $53.1^{\circ}$ that indicate the presence of a minor $\mathrm{Ni}_{5} \mathrm{P}_{4}$ impurity. There is no indication in the $\mathrm{XRD}$ pattern for the presence of $\mathrm{Ni}_{3}\left(\mathrm{PO}_{4}\right)_{2}, \mathrm{Ni}_{2} \mathrm{P}_{2} \mathrm{O}_{7}$ or $\mathrm{Ni}\left(\mathrm{PO}_{3}\right)_{2}$ as byproducts in the reduction of $\mathrm{Ni}\left(\mathrm{H}_{2} \mathrm{PO}_{2}\right)_{2}$. These results provide strong evidence that $\mathrm{H}_{3} \mathrm{PO}_{4}$ is the $\mathrm{P}$-containing byproduct formed, as proposed in Equation 5. The TPR-MS spectrum (Figure 2) indicates that adsorbed $\mathrm{H}_{3} \mathrm{PO}_{4}$ on the surface of the $\mathrm{Ni}_{2} \mathrm{P}$ particles is reduced above $750 \mathrm{~K}$, as proposed in the following overall reaction: $2 \mathrm{H}_{3} \mathrm{PO}_{4}+5 \mathrm{H}_{2} \rightarrow 2 \mathrm{P}+8 \mathrm{H}_{2} \mathrm{O}$. The envelope of overlapping $\mathrm{H}_{2} \mathrm{O}$ evolution peaks in the $750-1050 \mathrm{~K}$ range indicates that this reduction occurs via sequence of hydrogenation steps. This $\mathrm{H}_{2} \mathrm{O}$ evolution profile is quite different from that reported previously for unsupported $\mathrm{Ni}_{2} \mathrm{P}_{2} \mathrm{O}_{7}$, for which TPR-MS showed $\mathrm{H}_{2} \mathrm{O}$ evolution only starting at $\sim 873$ with small and large peaks at 953 and $993 \mathrm{~K}$, respectively [17]. 
TPR-MS traces for $\mathrm{SiO}_{2^{-}}, \gamma-\mathrm{Al}_{2} \mathrm{O}_{3^{-}}$and ASA-supported Ni hypophosphite precursors are shown in Figure 3. Relative to unsupported $\mathrm{Ni}\left(\mathrm{H}_{2} \mathrm{PO}_{2}\right)_{2} \cdot 6 \mathrm{H}_{2} \mathrm{O}$, the TPR-MS traces are more complex, showing differences depending on the support material. Removal of the waters of hydration (and adsorbed $\mathrm{H}_{2} \mathrm{O}$ ) was observed in broad peaks with maxima in the 393-413 $\mathrm{K}$ range, while $\mathrm{H}_{2} \mathrm{O}$ evolved in peaks at 481-566 K can be assigned to reaction of the supported $\mathrm{Ni}\left(\mathrm{H}_{2} \mathrm{PO}_{2}\right)_{2}$.

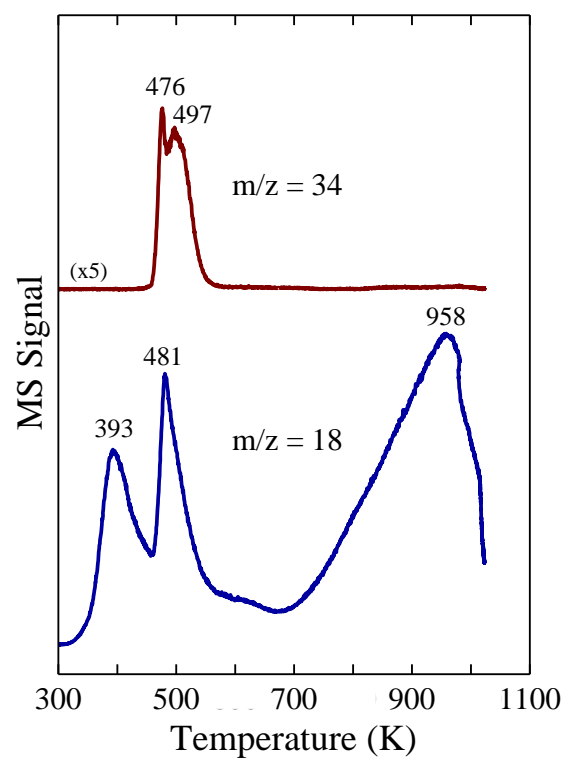

(a)

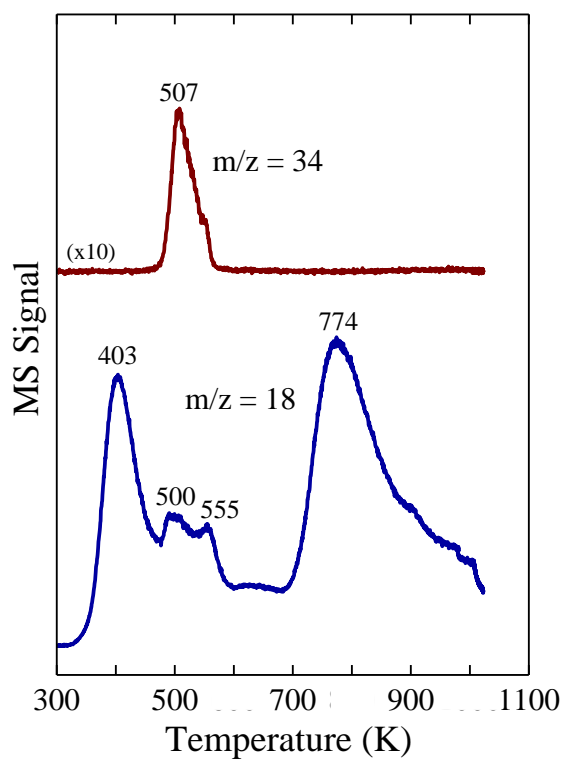

(b)

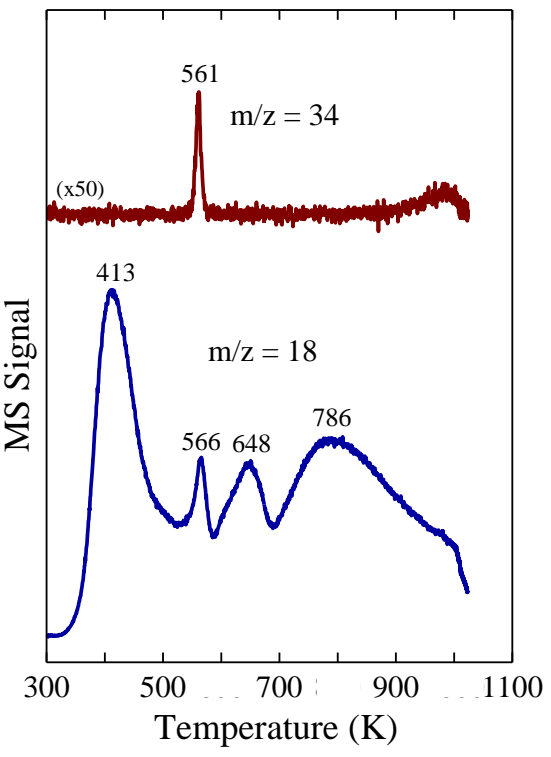

(c)

Figure 3: TPR-MS traces for (a) $\mathrm{Ni}\left(\mathrm{H}_{2} \mathrm{PO}_{2}\right)_{2} / \mathrm{SiO}_{2}$, (b) $\mathrm{Ni}\left(\mathrm{H}_{2} \mathrm{PO}_{2}\right)_{2} / \mathrm{Al}_{2} \mathrm{O}_{3}$, and $\mathrm{Ni}\left(\mathrm{H}_{2} \mathrm{PO}_{2}\right)_{2} / \mathrm{ASA}$ in $10 \% \mathrm{H}_{2} / \mathrm{Ar}$.

The quantity and temperature of $\mathrm{PH}_{3}$ evolution depended strongly on the support, with the largest amount and the lowest temperature observed for $\mathrm{SiO}_{2}$, and then progressively lower amounts and higher temperatures observed for $\gamma-\mathrm{Al}_{2} \mathrm{O}_{3}$ and $\mathrm{ASA}$ in that order. While the $\mathrm{PH}_{3}$ evolution peaks are broader than for unsupported $\mathrm{Ni}\left(\mathrm{H}_{2} \mathrm{PO}_{2}\right)_{2}$, and shifted to higher temperatures, the coincident evolution of $\mathrm{H}_{2} \mathrm{O}$ is consistent with the reaction shown in Equation 5. High temperature $\mathrm{H}_{2} \mathrm{O}$ evolution peaks with maxima in the 774-958 $\mathrm{K}$ range are assigned to the reaction of $\mathrm{H}_{2}$ with 
surface-bonded $\mathrm{H}_{\mathrm{x}} \mathrm{PO}_{4}{ }^{(3-\mathrm{x})-}$ species. The $\mathrm{H}_{2} \mathrm{O}$ evolution peak observed at an intermediate temperature $(648 \mathrm{~K})$ for $\mathrm{Ni}\left(\mathrm{H}_{2} \mathrm{PO}_{2}\right)_{2} / \mathrm{ASA}$ is more difficult to assign, but the absence of a $\mathrm{PH}_{3}$ peak at this temperature suggests that it is not due to reaction of a phosphite species as was assigned in the case of $\mathrm{NaH}_{2} \mathrm{PO}_{2}$ in $10 \% \mathrm{H}_{2} / \mathrm{Ar}$.

\subsection{Catalyst Characterization}

XRD patterns for the precursors of the supported $\mathrm{Ni}_{2} \mathrm{P}$ catalysts subjected to TPR to

272 increasing temperatures in flowing $\mathrm{H}_{2}$ are shown in Figure 4; the temperature at which $\mathrm{Ni}_{2} \mathrm{P}$ was

273 observed depends on the support material. Phase purity was determined by comparing the XRD

274 patterns to those of reference phases in the JCPDS database $\left(\mathrm{Ni}_{2} \mathrm{P}: \# 089-2742, \mathrm{Ni}_{12} \mathrm{P}_{5}\right.$ : \#22-1190

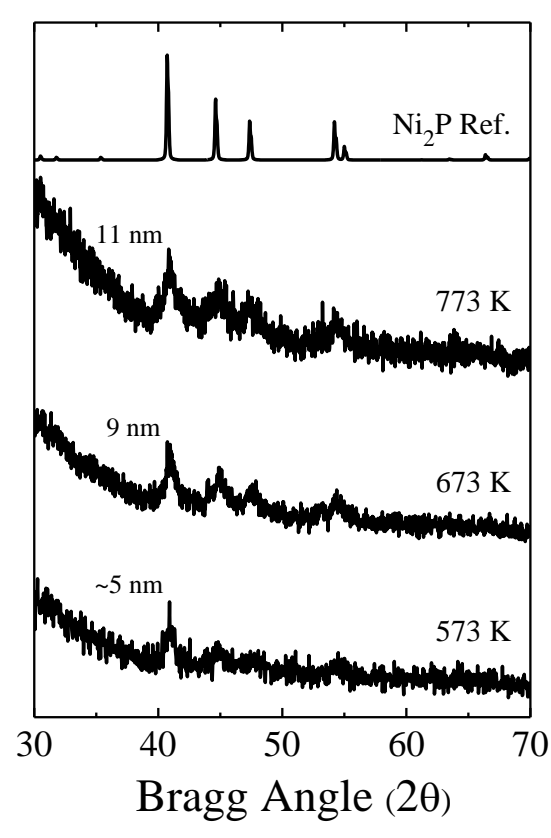

(a)

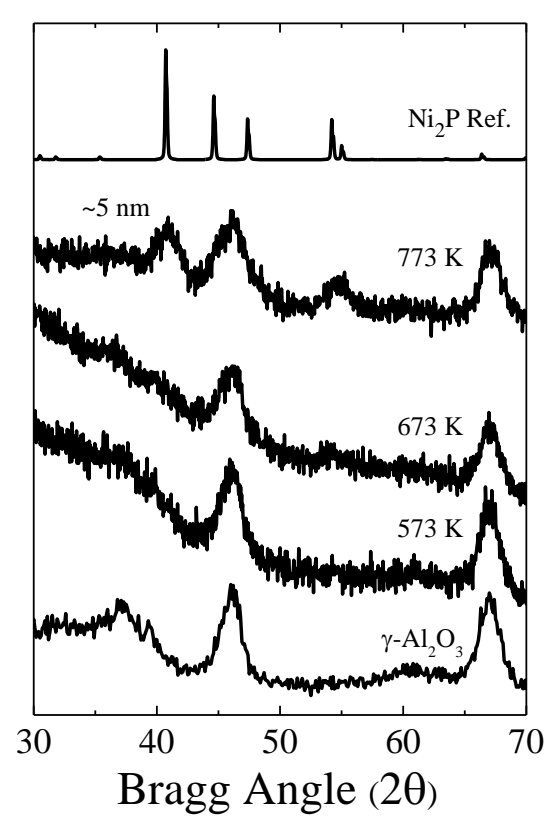

(b)

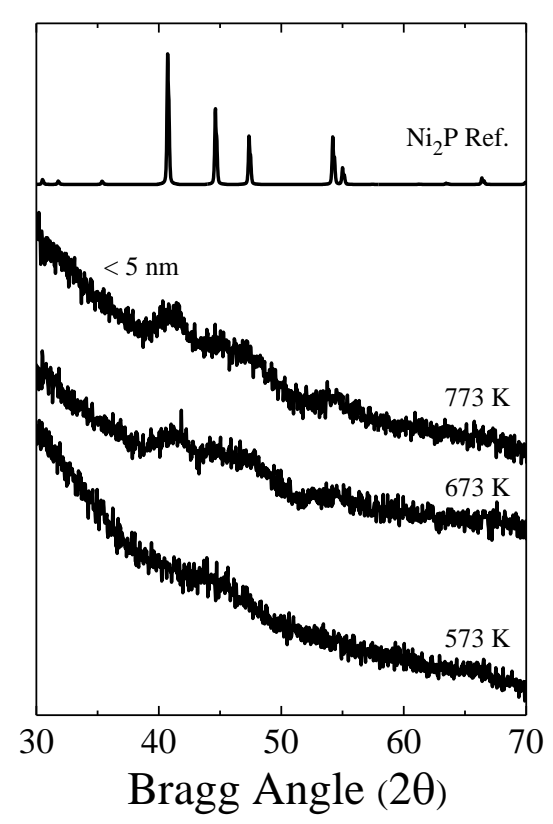

(c)

Figure 4: XRD patterns for (a) $\mathrm{Ni}\left(\mathrm{H}_{2} \mathrm{PO}_{2}\right)_{2} / \mathrm{SiO}_{2}$, (b) $\mathrm{Ni}\left(\mathrm{H}_{2} \mathrm{PO}_{2}\right)_{2} / \mathrm{Al}_{2} \mathrm{O}_{3}$, and $\mathrm{Ni}\left(\mathrm{H}_{2} \mathrm{PO}_{2}\right)_{2} / \mathrm{ASA}$ subjected to TPR in flowing $\mathrm{H}_{2}$ to the indicated temperatures. The average $\mathrm{Ni}_{2} \mathrm{P}$ crystallite sizes are noted on the XRD plots. 
$275[18]$ ) and average crystallite sizes were calculated using the Scherrer equation and the $\{111\}$ peak at $27640.8^{\circ}$.

277 In the case of $\mathrm{SiO}_{2}$, phase pure $\mathrm{Ni}_{2} \mathrm{P}$ having an average crystallite size of $\sim 5 \mathrm{~nm}$ was observed by $278573 \mathrm{~K}$; increasing the TPR temperature led to the formation of larger $\mathrm{Ni}_{2} \mathrm{P}$ crystallites. These 279 results are consistent with the findings of others for the preparation of $\mathrm{Ni}_{2} \mathrm{P} / \mathrm{SiO}_{2}$ catalysts using 280 hypophosphite as the $\mathrm{P}$ source, while noting that the catalysts prepared in these other studies 281 utilized $\mathrm{H}_{2} \mathrm{O}$ washing steps to remove salt byproducts (e.g. $\mathrm{NaCl}$ ) formed during catalyst synthesis $282[9,10,16]$. The XRD patterns for the $\mathrm{Ni}\left(\mathrm{H}_{2} \mathrm{PO}_{2}\right)_{2} / \mathrm{Al}_{2} \mathrm{O}_{3}$, and $\mathrm{Ni}\left(\mathrm{H}_{2} \mathrm{PO}_{2}\right)_{2} /$ ASA samples subjected to 283 TPR exhibit peaks for $\mathrm{Ni}_{2} \mathrm{P}$ at higher temperatures than for the $\mathrm{Ni}\left(\mathrm{H}_{2} \mathrm{PO}_{2}\right)_{2} / \mathrm{SiO}_{2}$, with broad peaks 284 apparent only after TPR at $773 \mathrm{~K}$. The average $\mathrm{Ni}_{2} \mathrm{P}$ crystallite sizes determined from the $773 \mathrm{~K}$ 285 XRD patterns are small $(\leq 5 \mathrm{~nm})$ and, given that the TPR-MS traces indicate $\mathrm{Ni}\left(\mathrm{H}_{2} \mathrm{PO}_{2}\right)_{2}$ undergoes 286 reaction on these supports at $500-575 \mathrm{~K}$, it is likely that smaller $\mathrm{Ni}_{2} \mathrm{P}$ crystallites were present at 287 lower temperatures, but in sizes below the detection limit of XRD. Since the XRD peaks for the ex 288 situ prepared $\mathrm{Ni}_{2} \mathrm{P} / \mathrm{Al}_{2} \mathrm{O}_{3}$ and $\mathrm{Ni}_{2} \mathrm{P} / \mathrm{ASA}$ catalysts are broad, it is not possible to exclude the 289 possibility of minor $\mathrm{Ni}_{12} \mathrm{P}$ impurities being present in these catalysts. However, the TEM and EDX 290 results described below are consistent with the presence of phase-pure $\mathrm{Ni}_{2} \mathrm{P}$ in these catalysts. 
(a)

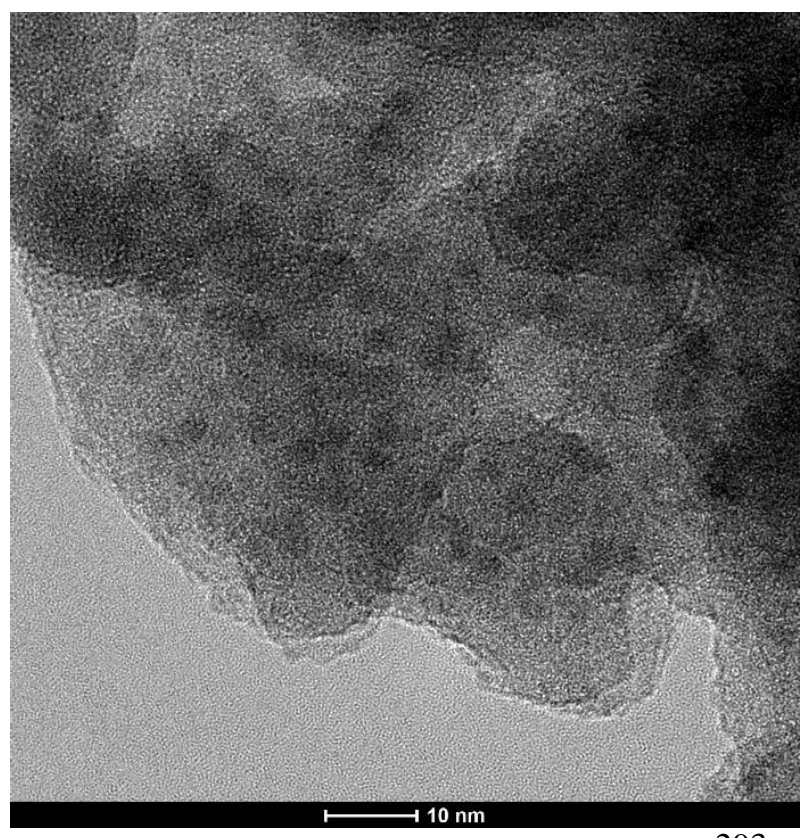

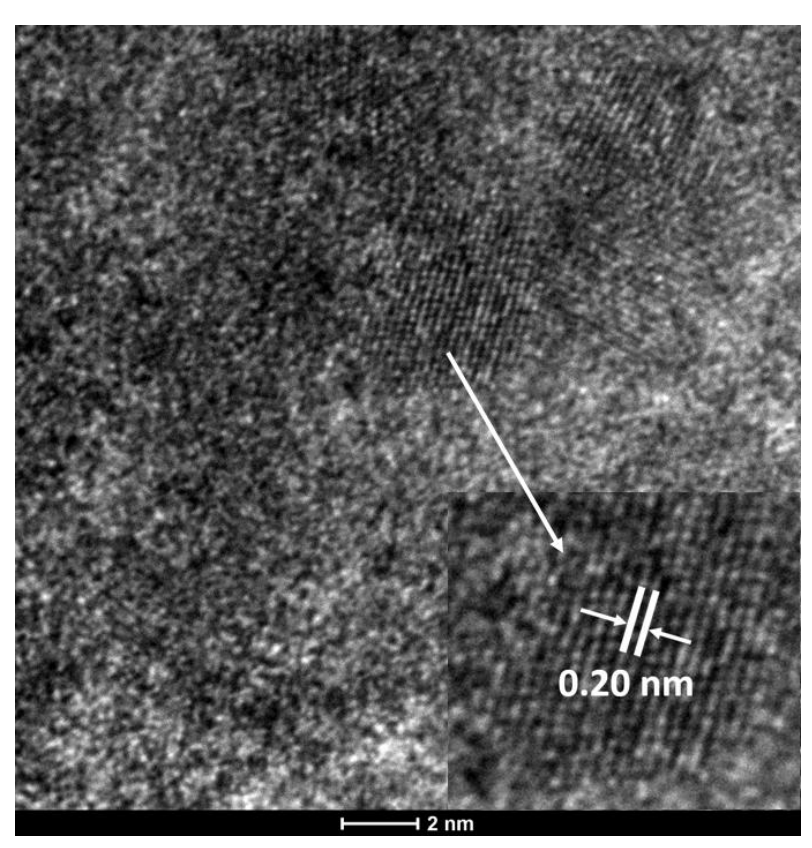

293

294

(b)
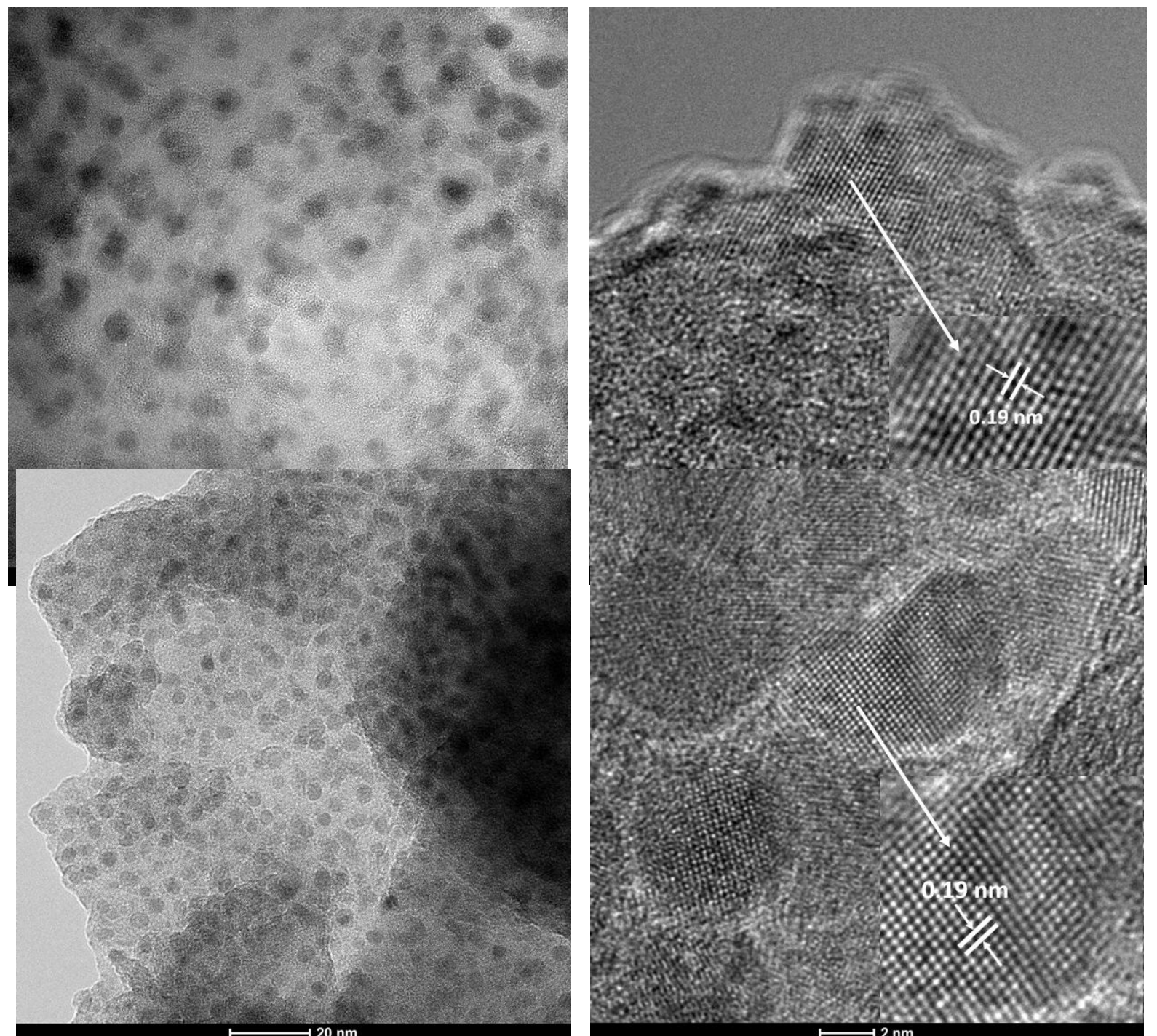

(c)

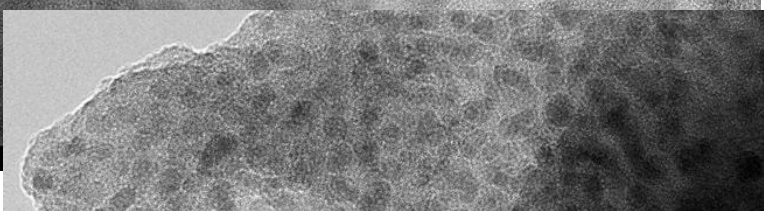


Figure 5: TEM images of ex situ prepared (a) $\mathrm{Ni}_{2} \mathrm{P} / \mathrm{SiO}_{2}$, (b) $\mathrm{Ni}_{2} \mathrm{P} / \mathrm{Al}_{2} \mathrm{O}_{3}$ and (c) $\mathrm{Ni} 2 \mathrm{P} / \mathrm{ASA}$ catalysts.

The low-resolution images reveal even dispersions of the $\mathrm{Ni}_{2} \mathrm{P}$ particles on the oxide supports; particle size measurements of $25-50 \mathrm{Ni}_{2} \mathrm{P}$ particles yielded average particle sizes in the $3-4 \mathrm{~nm}$ range (Table 1). The average $\mathrm{Ni}_{2} \mathrm{P}$ particle size for the $\mathrm{Ni}_{2} \mathrm{P} / \mathrm{SiO}_{2}$ is significantly smaller than the average $\mathrm{Ni}_{2 \mathrm{P}}$ crystallite size of $9 \mathrm{~nm}$ determined for this catalyst using the Scherrer method. This discrepancy is likely due to the fact that only a few of the $\mathrm{Ni}_{2} \mathrm{P}$ particles are large enough to be detected by XRD. The high-resolution images for the $\mathrm{Ni}_{2} \mathrm{P} / \mathrm{Al}_{2} \mathrm{O}_{3}$ and $\mathrm{Ni}_{2} \mathrm{P} / \mathrm{ASA}$ catalysts show lattice fringes having spacings of $0.19 \mathrm{~nm}$ that are assigned to the $\{210\}$ crystallographic planes of $310 \mathrm{Ni}_{2} \mathrm{P}$, which have a d-spacing of $0.192 \mathrm{~nm}$. The spacing between lattice fringes of the $\mathrm{Ni}_{2} \mathrm{P} / \mathrm{SiO}_{2}$ catalyst was slightly larger $(0.20 \mathrm{~nm})$, but the uncertainty was also higher because of the lower 312 quality of the TEM image for this catalyst. The observed d-spacings are consistent with those reported by others for $\mathrm{Ni}_{2} \mathrm{P} / \mathrm{MCM}-41$ catalysts prepared using hypophosphite as the $\mathrm{P}$ source $[9,11]$.

314 Particle compositions determined using EDX (averaged for 5-7 particles) for the ex situ prepared $315 \mathrm{Ni}_{2} \mathrm{P} / \mathrm{SiO}_{2}, \mathrm{Ni}_{2} \mathrm{P} / \mathrm{Al}_{2} \mathrm{O}_{3}$ and $\mathrm{Ni}_{2} \mathrm{P} / \mathrm{ASA}$ catalysts are close to that for $\mathrm{Ni}_{2} \mathrm{P}$ (Table 1$)$.

316 The BET surface areas, CO chemisorption capacities and other characterization data for the 317 supported $\mathrm{Ni}_{2} \mathrm{P}$ catalysts prepared from hypophosphite- and phosphate-based precursors are 318 summarized in Table 1. 
Table 1: Characterization Data for Supported $\mathrm{Ni}_{2} \mathrm{P}$ Catalysts

\begin{tabular}{|c|c|c|c|c|c|c|c|}
\hline & Catalyst & $\begin{array}{c}\text { Precursor } \\
\text { P/Ni } \\
\text { Ratio }\end{array}$ & $\begin{array}{c}\text { EDX } \\
\text { Particle } \\
\text { composit } \\
\text { ion }\end{array}$ & $\begin{array}{c}\text { Average } \\
\mathrm{Ni}_{2} \mathbf{P} \\
\text { Crystallite } \\
\text { Size }(\mathbf{n m})^{\mathbf{a}}\end{array}$ & $\begin{array}{c}\text { Average } \\
\mathrm{Ni}_{2} \mathbf{P} \\
\text { particle } \\
\text { size }(\mathbf{n m})^{\mathrm{c}}\end{array}$ & $\begin{array}{c}\text { BET } \\
\text { Surface } \\
\text { Area } \\
\left(\mathbf{m}^{2} / \mathbf{g}\right)\end{array}$ & $\begin{array}{c}\text { CO } \\
\text { Chemisorption } \\
\text { Capacity } \\
(\mu \mathrm{mol} / \mathrm{g})\end{array}$ \\
\hline \multirow{3}{*}{ 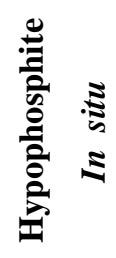 } & $\mathrm{Ni}_{2} \mathrm{P} / \mathrm{SiO}_{2}$ & 1.5 & ---- & ---- & ---- & 199 & 43 \\
\hline & $\mathrm{Ni}_{2} \mathrm{P} / \mathrm{Al}_{2} \mathrm{O}_{3}$ & 2.0 & ---- & --- & ---- & 159 & 57 \\
\hline & $\mathrm{Ni}_{2} \mathrm{P} / \mathrm{ASA}$ & 2.0 & ---- & ---- & ---- & 132 & 81 \\
\hline \multirow{3}{*}{ 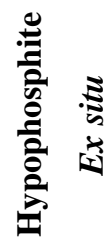 } & $\mathrm{Ni}_{2} \mathrm{P} / \mathrm{SiO}_{2}$ & 1.5 & $\mathrm{Ni}_{2.11} \mathrm{P}_{1.00}$ & 9 & $3.2 \pm 0.4$ & 202 & 51 \\
\hline & $\mathrm{Ni}_{2} \mathrm{P} / \mathrm{Al}_{2} \mathrm{O}_{3}$ & 2.0 & $\mathrm{Ni}_{2.07} \mathrm{P}_{1.00}$ & $<5$ & $3.9 \pm 0.6$ & 115 & 46 \\
\hline & $\mathrm{Ni}_{2} \mathrm{P} / \mathrm{ASA}$ & 2.0 & $\mathrm{Ni}_{2.16} \mathrm{P}_{1.00}$ & $<5$ & $3.3 \pm 0.5$ & 120 & 55 \\
\hline \multirow{3}{*}{ 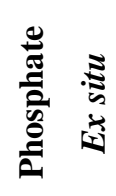 } & $\mathrm{Ni}_{2} \mathrm{P} / \mathrm{SiO}_{2}$ & 0.9 & ---- & $12^{\mathrm{b}}$ & ---- & $132^{\mathrm{b}}$ & $113^{\mathrm{b}}$ \\
\hline & $\mathrm{Ni}_{2} \mathrm{P} / \mathrm{Al}_{2} \mathrm{O}_{3}$ & 1.5 & ---- & 19 & ---- & 97 & 52 \\
\hline & $\mathrm{Ni}_{2} \mathrm{P} / \mathrm{ASA}$ & 2.2 & ---- & 13 & --- & 153 & 19 \\
\hline
\end{tabular}

${ }^{\mathrm{a}}$ Calculated for ex situ prepared catalysts using XRD patterns after TPR to a maximum temperature of $673 \mathrm{~K}$

${ }^{\mathrm{b}}$ Data taken from [3].

${ }^{\mathrm{c}}$ Calculated for ex situ prepared catalysts using TEM images after TPR to a maximum temperature of $673 \mathrm{~K}$

In the case of the catalysts prepared from hypophosphite-based precursors, data are provided for catalysts prepared in situ as well as ex situ. The ex situ prepared catalysts were passivated after synthesis, transferred through air to the Autochem $2950 \mathrm{HP}$ instrument and then reduced at $673 \mathrm{~K}$ in flowing $\mathrm{H}_{2}$ prior to $\mathrm{CO}$ chemisorption and BET measurements. The in situ prepared catalysts were loaded into the Autochem $2950 \mathrm{HP}$ system in precursor form, and converted to $\mathrm{Ni}_{2} \mathrm{P}$ by $\mathrm{TPR}$ in flowing $\mathrm{H}_{2}$ to $673 \mathrm{~K}$ just prior to the $\mathrm{CO}$ chemisorption and BET measurements.

Except for the $\mathrm{Ni}_{2} \mathrm{P} / \mathrm{ASA}$ catalysts, the supported $\mathrm{Ni}_{2} \mathrm{P}$ catalysts prepared from hypophosphite precursors had higher BET surface areas compared to catalysts prepared from phosphate-based precursors. This same trend was observed for the $\mathrm{CO}$ chemisorption capacities, except that for 
$\mathrm{Ni}_{2} \mathrm{P} / \mathrm{SiO}_{2}$ the catalyst prepared from the phosphate precursor had the highest chemisorption capacity.

Surface compositions were determined by XPS for the hypophosphite precursors and the $\mathrm{Ni}_{2} \mathrm{P}$ catalysts prepared ex situ from them, as well as for some of the in situ and ex situ prepared catalysts after catalytic testing; these compositions are listed in Table 2.

Table 2: Catalyst Surface Compositions determined by XPS

\begin{tabular}{|c|c|c|c|c|}
\hline & \multirow{2}{*}{ Catalyst } & \multicolumn{3}{|c|}{ Surface Composition } \\
\hline & & Precursor & $\begin{array}{c}\text { Ex situ } \\
\text { Prepared }\end{array}$ & $\begin{array}{c}\text { Post-HDN/HDS } \\
\text { Testing }\end{array}$ \\
\hline 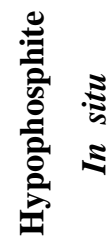 & $\begin{array}{c}\mathrm{Ni}_{2} \mathrm{P} / \mathrm{SiO}_{2} \\
\mathrm{Ni}_{2} \mathrm{P} / \mathrm{Al}_{2} \mathrm{O}_{3} \\
\mathrm{Ni}_{2} \mathrm{P} / \mathrm{ASA}\end{array}$ & $\begin{array}{l}\mathrm{Ni}_{2.00} \mathrm{P}_{3.14} \\
\mathrm{Ni}_{2.00} \mathrm{P}_{4.57} \\
\mathrm{Ni}_{2.00} \mathrm{P}_{2.88}\end{array}$ & $\begin{array}{l}--- \\
---- \\
----\end{array}$ & $\begin{array}{c}\mathrm{Ni}_{2.00} \mathrm{P}_{6.23} \\
\mathrm{Ni}_{2.00} \mathrm{P}_{11.31} \\
-----\end{array}$ \\
\hline 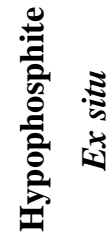 & $\begin{array}{c}\mathrm{Ni}_{2} \mathrm{P} / \mathrm{SiO}_{2} \\
\mathrm{Ni}_{2} \mathrm{P} / \mathrm{Al}_{2} \mathrm{O}_{3} \\
\mathrm{Ni}_{2} \mathrm{P} / \mathrm{ASA}\end{array}$ & $\begin{array}{l}\mathrm{Ni}_{2.00} \mathrm{P}_{3.14} \\
\mathrm{Ni}_{2.00} \mathrm{P}_{4.57} \\
\mathrm{Ni}_{2.00} \mathrm{P}_{2.88}\end{array}$ & $\begin{array}{l}\mathrm{Ni}_{2.00} \mathrm{P}_{3.71} \\
\mathrm{Ni}_{2.00} \mathrm{P}_{5.69} \\
\mathrm{Ni}_{2.00} \mathrm{P}_{6.33}\end{array}$ & $\begin{array}{c}\mathrm{Ni}_{2.00} \mathrm{P}_{6.04} \\
\mathrm{Ni}_{2.00} \mathrm{P}_{11.84} \\
----\end{array}$ \\
\hline
\end{tabular}

342 surf

343 ace
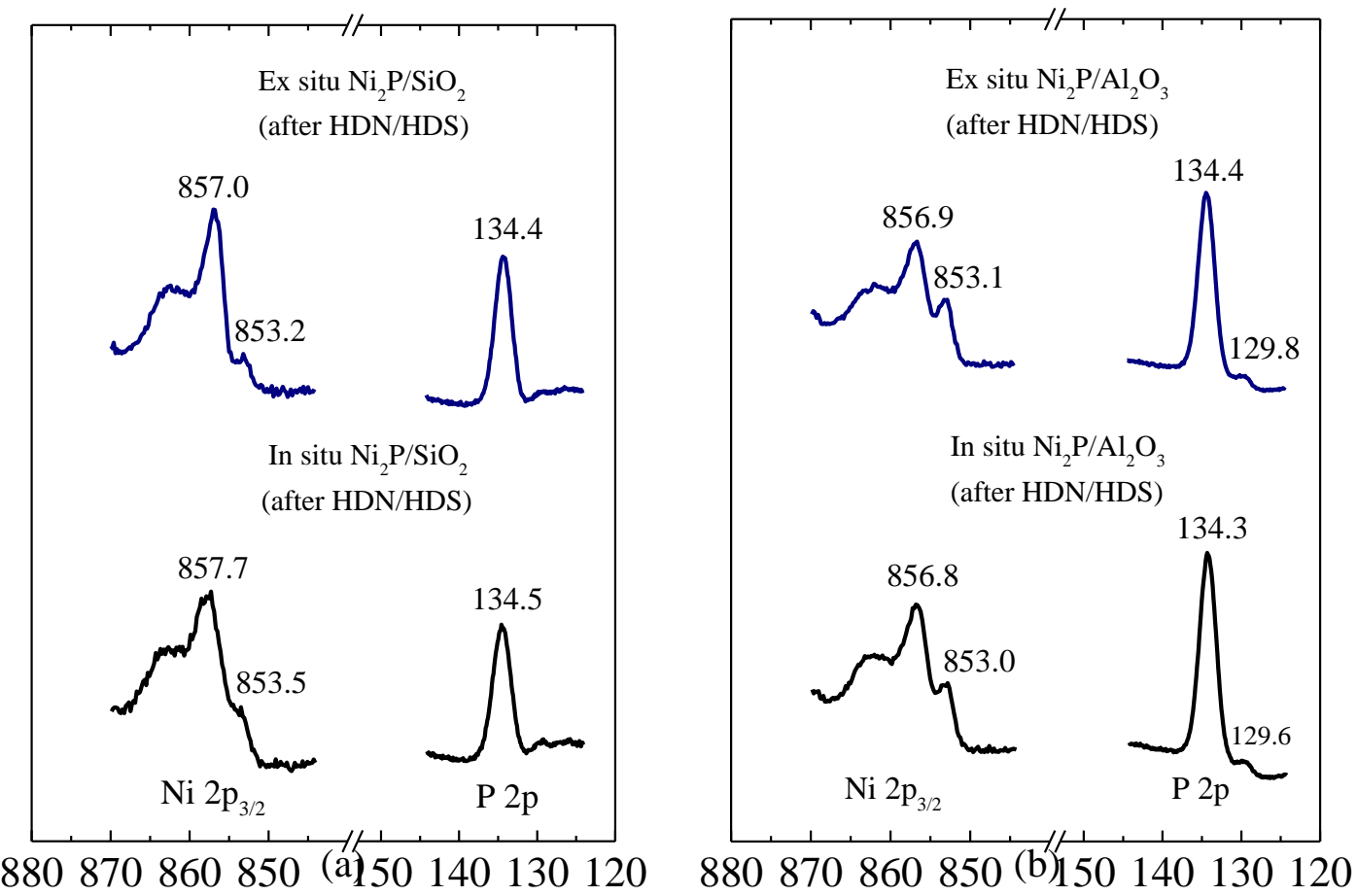

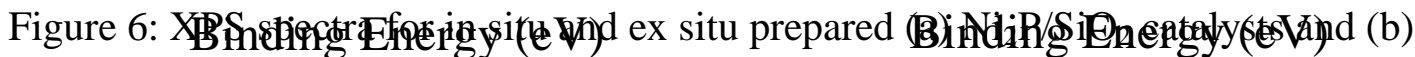
$\mathrm{Ni}_{2} \mathrm{P} / \mathrm{Al}_{2} \mathrm{O}_{3}$, with all spectra acquired after HDN/HDS testing. 
ed for the hypophosphite precursors, ex situ prepared $\mathrm{Ni}_{2} \mathrm{P}$ catalysts, and HDN/HDS-tested catalysts are high relative to the stoichiometry of $\mathrm{Ni}_{2} \mathrm{P}(\mathrm{P} / \mathrm{Ni}=0.5)$. Interestingly, the surface P-enrichment increases from the precursor to the ex situ prepared $\mathrm{Ni}_{2} \mathrm{P}$ catalysts, and further for the HDN/HDStested catalysts. Plotted in Figure 6 are the XPS spectra in the $\mathrm{Ni}\left(2 \mathrm{p}_{3 / 2}\right)$ and $\mathrm{P}(2 \mathrm{p})$ regions for the in situ and ex situ prepared $\mathrm{Ni}_{2} \mathrm{P} / \mathrm{SiO}_{2}$ and $\mathrm{Ni}_{2} \mathrm{P} / \mathrm{Al}_{2} \mathrm{O}_{3}$ catalysts after $\mathrm{HDN} / \mathrm{HDS}$ testing.

Upon completion of an HDN/HDS measurement, the reactor was purged with $\mathrm{H}_{2}$ for $1 \mathrm{~h}$ at the reaction temperature, $\mathrm{He}$ for $30 \mathrm{~min}$ at room temperature, and then the catalysts were passivated in a1 $\mathrm{mol} \% \mathrm{O}_{2} / \mathrm{He}$ mixture prior to removal from the reactor for the XPS analyses.

No substantive differences were observed between the XPS spectra of the HDN/HDS-tested samples of the in situ and ex situ prepared catalysts. As reported previously, the most intense peaks in the $\mathrm{Ni}\left(2 \mathrm{p}_{3 / 2}\right)$ and $\mathrm{P}(2 \mathrm{p})$ regions at $856.8-857.7$ and $134.3-134.5 \mathrm{eV}$ are assigned to $\mathrm{Ni}^{2+}$ and $\mathrm{P}^{5+}$ species, respectively, while weaker peaks at 853.0-853.5 and 129.6-129.8 eV are assigned to reduced $\mathrm{Ni}$ and $\mathrm{P}$ species having oxidation states near zero $[5,19]$. The low oxidation state species are assigned to $\mathrm{Ni}$ and $\mathrm{P}$ in $\mathrm{Ni}_{2} \mathrm{P}$. The higher oxidation state species are assigned to $\mathrm{Ni}$ and $\mathrm{P}$ in the passivation layer at the surface of the $\mathrm{Ni}_{2} \mathrm{P}$ particles, but could also be associated with unreduced species (e.g. $\mathrm{H}_{\mathrm{x}} \mathrm{PO}_{4}{ }^{(3-\mathrm{x})}$ ) ) produced during the synthesis. Such phosphate species would not be expected to be reduced under the synthesis or reaction conditions used in which the temperature did not exceed $673 \mathrm{~K}$. Comparison of the XPS spectra and surface compositions of the hypophosphitebased $\mathrm{Ni}_{2} \mathrm{P} / \mathrm{SiO}_{2}$ and $\mathrm{Ni}_{2} \mathrm{P} / \mathrm{Al}_{2} \mathrm{O}_{3}$ catalysts to XPS results published previously for catalysts prepared from phosphate-based precursors reveals some important differences. The ex situ prepared, hypophosphite-based $\mathrm{Ni}_{2} \mathrm{P} / \mathrm{SiO}_{2}$ catalyst exhibited a surface $\mathrm{P} / \mathrm{Ni}$ ratio of 1.9 , which is substantially higher than values reported for $\mathrm{Ni}_{2} \mathrm{P} / \mathrm{SiO}_{2}$ catalysts prepared from phosphate based precursors (surface $\mathrm{P} / \mathrm{Ni}=0.43-0.68$ ) $[3,5,19]$. This difference can be attributed to a dramatically larger $\mathrm{P}(2 \mathrm{p})$ peak for oxidized $\mathrm{P}$ at $134-134.5 \mathrm{eV}$ for the hypophosphite-based $\mathrm{Ni}{ }_{2} \mathrm{P} / \mathrm{SiO}_{2}$ catalyst 
374 than for the catalysts prepared from phosphate-based precursors. On the other hand, the ex situ 375 prepared, hypophosphite-based $\mathrm{Ni}_{2} \mathrm{P} / \mathrm{Al}_{2} \mathrm{O}_{3}$ catalyst exhibited a surface $\mathrm{P} / \mathrm{Ni}$ ratio of 2.8 that is 376 significantly lower than what was observed for a $\mathrm{Ni}_{2} \mathrm{P} / \mathrm{Al}_{2} \mathrm{O}_{3}$ catalyst prepared from a phosphate377 based precursor (surface $\mathrm{P} / \mathrm{Ni}=4.0$ ) [5]. The surface compositions of the hypophosphite-based 378 catalysts analyzed by XPS after HDN/HDS testing ( surface P/Ni = 3.0-3.1 $\left(\mathrm{Ni}_{2} \mathrm{P} / \mathrm{SiO}_{2}\right)$ and 5.7-5.9 $\left.379\left(\mathrm{Ni}_{2} \mathrm{P} / \mathrm{Al}_{2} \mathrm{O}_{3}\right)\right)$ indicate dramatic surface $\mathrm{P}$ enrichment relative to ex situ prepared catalysts from 380 either hypophosphite- or phosphate-based precursors.

$381 \quad 3.3 \mathrm{HDN}$ and HDS Properties 
The catalytic properties of hypophosphite-based $\mathrm{Ni}_{2} \mathrm{P}$ catalysts on the $\mathrm{SiO}_{2}, \gamma-\mathrm{Al}_{2} \mathrm{O}_{3}$ and 
ASA supports were evaluated using a mixed carbazole/benzothiophene feed and were compared with the properties of phosphate-based $\mathrm{Ni}_{2} \mathrm{P}$ catalysts on the same supports. In this study, the carbazole HDN conversion is defined as the conversion of carbazole and hydrogenated carbazoles to hydrocarbon products that do not contain nitrogen; the benzothiophene HDS conversion is

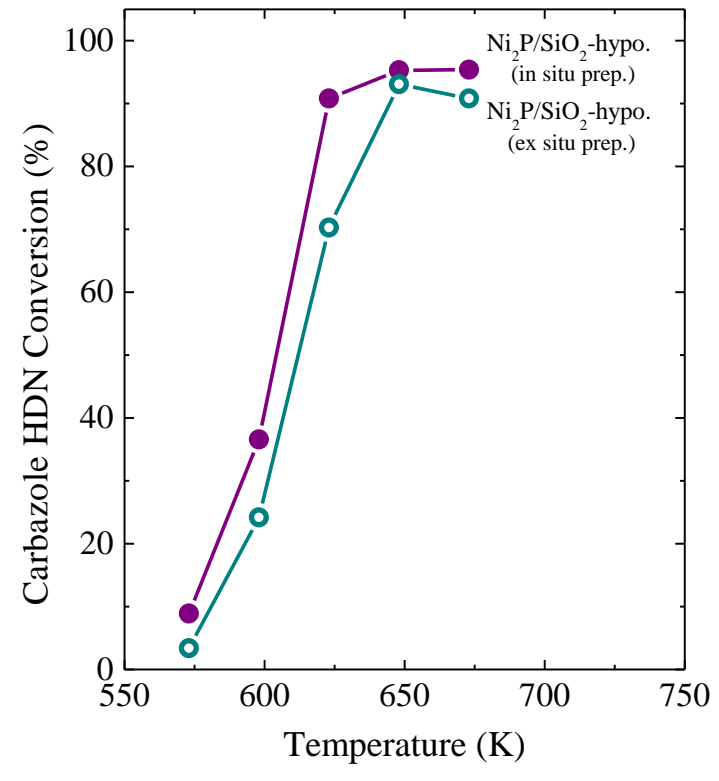

(a)

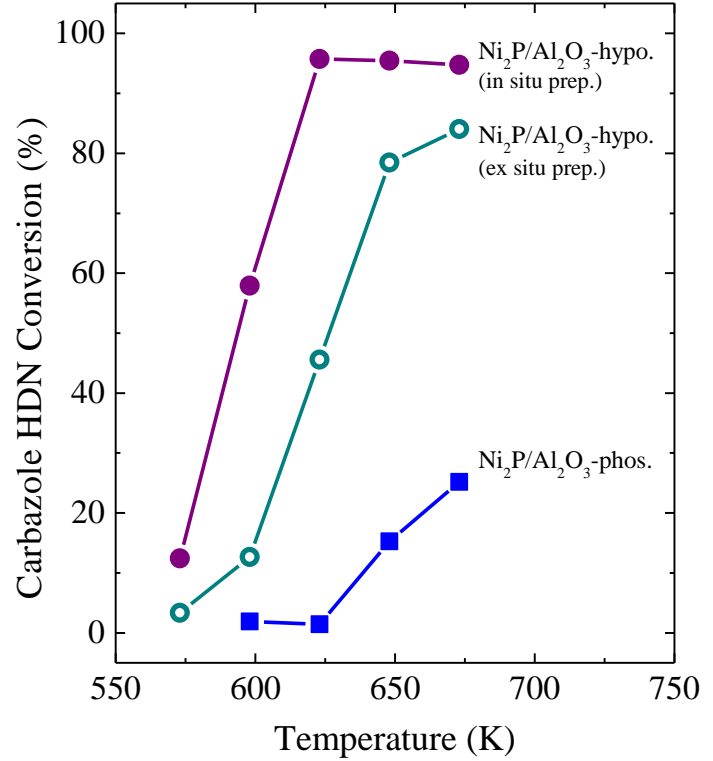

(b)

defined similarly. Shown in Figure 7 are the carbazole HDN conversions plotted as a function of the reaction temperature.

Figure 7: Carbazole HDN conversion vs. temperature for (a) $\mathrm{Ni}_{2} \mathrm{P} / \mathrm{SiO}_{2}$, (b) $\mathrm{Ni}_{2} \mathrm{P} / \mathrm{Al}_{2} \mathrm{O}_{3}$, and (c) $\mathrm{Ni}_{2} \mathrm{P} / \mathrm{ASA}$ catalysts prepared from hypophosphite- and phosphate-based precursors.

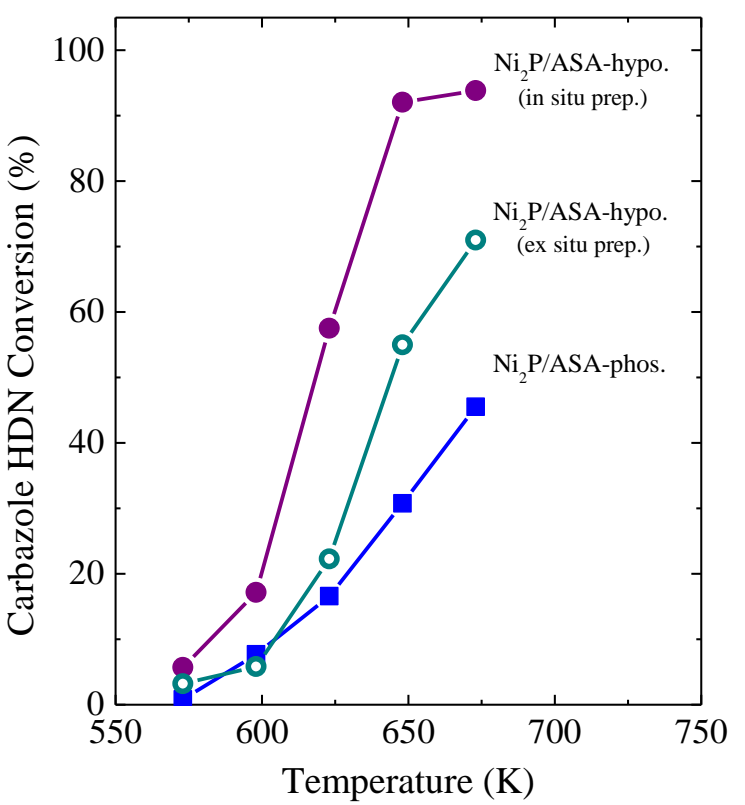


The carbazole $\mathrm{HDN}$ conversions were highest for the in situ prepared $\mathrm{Ni}_{2} \mathrm{P}$ catalysts on the three supports, with the phosphate-based $\mathrm{Ni}_{2} \mathrm{P}$ catalysts the least active by a 395

substantial margin for the $\gamma-\mathrm{Al}_{2} \mathrm{O}_{3}$ and ASA supports. The smallest difference between the in situ and ex situ hypophosphite-based catalysts was observed for the $\mathrm{Ni}_{2} \mathrm{P} / \mathrm{SiO}_{2}$ catalysts, which had similar carbazole HDN conversions as a phosphate-based $\mathrm{Ni}_{2} \mathrm{P} / \mathrm{SiO}_{2}$ that were reported elsewhere [3]. The benzothiophene HDS conversions of the $\mathrm{Ni}_{2} \mathrm{P}$ catalysts prepared in situ from hypophosphite-based precursors are plotted in Figure 8 ; $\mathrm{Ni}_{2} \mathrm{P}$ on the three different supports exhibited HDS conversions of $94 \%$ or higher at $623 \mathrm{~K}$ and above.

The carbazole HDN and benzothiophene HDS conversions at $623 \mathrm{~K}$ for the hypophosphite-based $\mathrm{Ni}_{2} \mathrm{P}$ catalysts on the $\mathrm{SiO}_{2}, \gamma-\mathrm{Al}_{2} \mathrm{O}_{3}$ and ASA supports are compared in Table 2 with those of phosphate-based $\mathrm{Ni}_{2} \mathrm{P}$ catalysts on the same supports. Also listed are the TOFs for each catalyst, 
421 calculated using the $\mathrm{CO}$ chemisorption capacities given in Table 1. For comparison purposes, 422 conversions and TOFs for a sulfided $\mathrm{Ni}-\mathrm{Mo} / \mathrm{Al}_{2} \mathrm{O}_{3}$ catalyst (Shell $424 ; 4 \mathrm{wt} \% \mathrm{NiO}, 19.5 \mathrm{wt} \%$ $423 \mathrm{MoO}_{3}, 8 \mathrm{wt} \% \mathrm{P}_{2} \mathrm{O}_{5}$ ) tested using the same feed and reactor conditions are also provided. The $424 \mathrm{Ni}_{2} \mathrm{P} / \mathrm{SiO}_{2}$ and $\mathrm{Ni}_{2} \mathrm{P} / \mathrm{Al}_{2} \mathrm{O}_{3}$ catalysts prepared in situ from hypophosphite precursors have higher $425 \mathrm{HDN}$ and HDS conversions and TOFs than does the sulfided Ni-Mo/ $\mathrm{Al}_{2} \mathrm{O}_{3}$ catalyst. Lower HDN 426 and HDS activities and TOFs were observed for the $\mathrm{Ni}_{2} \mathrm{P}$ catalysts prepared ex situ from 427 hypophosphite-based precursors and from phosphate-based precursors, with the exception of the $428 \quad \mathrm{Ni}_{2} \mathrm{P} / \mathrm{SiO}_{2}$ catalyst prepared using phosphate as the $\mathrm{P}$ source.

Table 3: HDN and HDS Conversions and Turnover Frequencies

\begin{tabular}{|c|c|c|c|c|c|}
\hline & \multirow{2}{*}{ Catalyst } & \multicolumn{2}{|c|}{ Conversion at $623 \mathrm{~K}$} & \multicolumn{2}{|c|}{ TOF at $623 \mathrm{~K}$} \\
\hline & & HDN (\%) & HDS (\%) & $\operatorname{HDN}\left(\mathrm{s}^{-1}\right) \times 10^{4}$ & $\operatorname{HDS}\left(\mathrm{s}^{-1}\right) \times 10^{3}$ \\
\hline \multirow{3}{*}{ 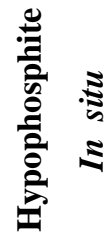 } & $\mathrm{Ni}_{2} \mathrm{P} / \mathrm{SiO}_{2}$ & 91 & 96 & 5.9 & 2.3 \\
\hline & $\mathrm{Ni}_{2} \mathrm{P} / \mathrm{Al}_{2} \mathrm{O}_{3}$ & 96 & 97 & 4.7 & 1.8 \\
\hline & $\mathrm{Ni}_{2} \mathrm{P} / \mathrm{ASA}$ & 58 & 94 & 2.0 & 1.2 \\
\hline \multirow{3}{*}{ 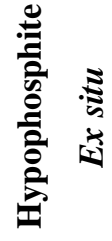 } & $\mathrm{Ni}_{2} \mathrm{P} / \mathrm{SiO}_{2}$ & 70 & 95 & 3.9 & 1.9 \\
\hline & $\mathrm{Ni}_{2} \mathrm{P} / \mathrm{Al}_{2} \mathrm{O}_{3}$ & 46 & 90 & 2.8 & 2.0 \\
\hline & $\mathrm{Ni}_{2} \mathrm{P} / \mathrm{ASA}$ & 22 & 84 & 1.1 & 1.6 \\
\hline \multirow{4}{*}{ 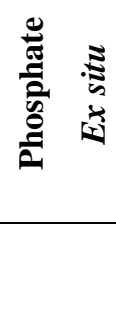 } & $\mathrm{Ni}_{2} \mathrm{P} / \mathrm{SiO}_{2}$ & $96^{\mathrm{a}}$ & $98^{\mathrm{a}}$ & 2.4 & 0.9 \\
\hline & $\mathrm{Ni}_{2} \mathrm{P} / \mathrm{Al}_{2} \mathrm{O}_{3}$ & 1.4 & 40 & 0.1 & 0.8 \\
\hline & $\mathrm{Ni}_{2} \mathrm{P} / \mathrm{ASA}$ & 17 & 71 & 2.4 & 3.9 \\
\hline & 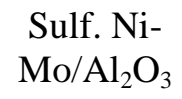 & $77^{\mathrm{a}}$ & $95^{\mathrm{a}}$ & 2.5 & 1.5 \\
\hline
\end{tabular}

431 The $\mathrm{Ni}_{2} \mathrm{P} / \mathrm{SiO}_{2}$ catalysts exhibited the least dependence of the HDS and HDN conversions and 432 TOFs on the preparation method, while the $\mathrm{Ni}_{2} \mathrm{P} / \mathrm{Al}_{2} \mathrm{O}_{3}$ and $\mathrm{Ni}_{2} \mathrm{P} / \mathrm{ASA}$ catalysts showed a strong 433 dependence. For $\mathrm{Ni}_{2} \mathrm{P}$ on the Al-containing supports, the catalysts prepared ex situ (hypophosphite 
434 and phosphate precursors) had significantly lower HDN and HDS conversions than the in situ 435 prepared catalysts. This trend was less pronounced for the TOFs, and was not followed for the $436 \quad \mathrm{Ni}_{2} \mathrm{P} / \mathrm{ASA}$ catalysts.

Carbazole $\mathrm{HDN}$ over a $\mathrm{Ni}_{2} \mathrm{P} / \mathrm{SiO}_{2}$ catalyst was investigated previously and the reaction network shown in Scheme 1 was proposed to account for the observed products [3]. The product of the direct denitrogenation (DDN) pathway, biphenyl (BP), was detected in only minor quantities $(<$ $1 \%$ ) and this pathway does not contribute appreciably to nitrogen removal from carbazole over the $441 \quad \mathrm{Ni}_{2} \mathrm{P}$ catalysts.

442

444

445

446

447

448

449

450

451

452

453

454

455

456

457

458 459

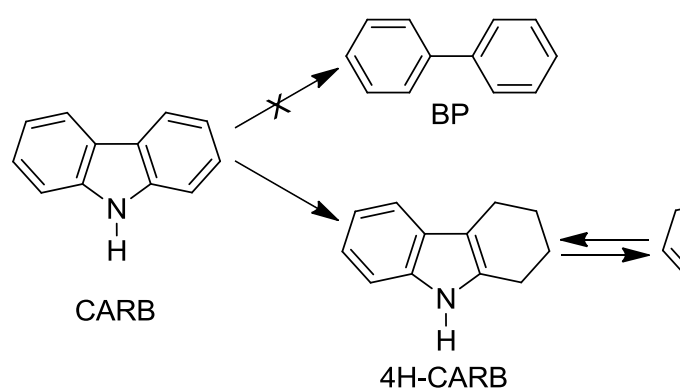

4H-CARB

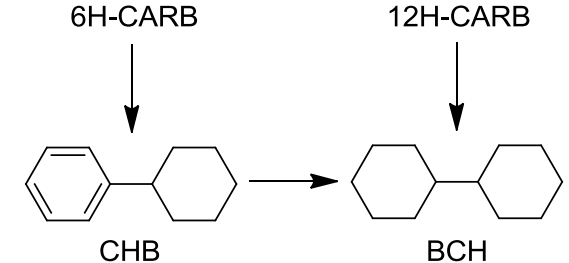

$\mathrm{CHB}$

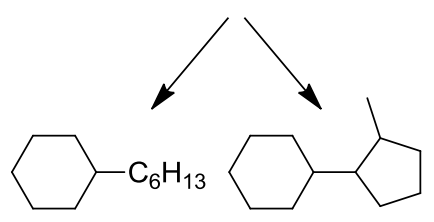

$\mathrm{HCH}$

Scheme 1: Carbazole $\mathrm{HDN}$ reaction network over $\mathrm{Ni}_{2} \mathrm{P}$ catalysts.

Three different hydrogenated carbazoles (4H-CARB, 6H-CARB, 12H-CARB) were observed, particularly at low reaction temperatures, and these are intermediates in the hydrogenation (HYD) pathway for carbazole HDN. The HDN product selectivities (i.e. excluding the carbazoles) at similar conversions (14-24\%) for the $\mathrm{Ni}_{2} \mathrm{P}$ catalysts prepared by the different methods are listed in Table 4. 
Table 4: Carbazole HDN Product Selectivities

\begin{tabular}{|c|c|c|c|c|c|c|c|c|c|c|}
\hline \multirow{2}{*}{$\begin{array}{c}\text { HDN } \\
\text { Product }\end{array}$} & \multirow{2}{*}{ 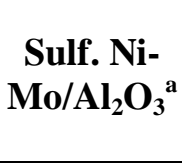 } & \multicolumn{3}{|c|}{$\mathrm{Ni}_{2} \mathrm{P} / \mathrm{SiO}_{2}$} & \multicolumn{3}{|c|}{$\mathrm{Ni}_{2} \mathbf{P} / \mathbf{A l}_{2} \mathrm{O}_{3}$} & \multicolumn{3}{|c|}{$\mathbf{N i}_{2} \mathbf{P} / \mathbf{A S A}$} \\
\hline & & $\begin{array}{l}\text { Hypo. } \\
\text { In situ }\end{array}$ & $\begin{array}{c}\text { Hypo. } \\
\text { Ex situ }\end{array}$ & Phos. & $\begin{array}{l}\text { Hypo. } \\
\text { In situ }\end{array}$ & $\begin{array}{c}\text { Hypo } \\
\text { Ex situ }\end{array}$ & Phos. & $\begin{array}{l}\text { Hypo. } \\
\text { In situ }\end{array}$ & $\begin{array}{c}\text { Hypo. } \\
\text { Ex situ }\end{array}$ & Phos. \\
\hline $\mathrm{BP}$ & 0.7 & 0.5 & 0.5 & 0.0 & 5.2 & 1.1 & 1.9 & 1.1 & 0.9 & 0.0 \\
\hline $\mathrm{CHB}$ & 15.8 & 45.8 & 43.6 & 43.0 & 47.8 & 37.9 & 63.6 & 50.1 & 53.4 & 63.0 \\
\hline $\mathrm{BCH}$ & 54.0 & 16.5 & 11.2 & 15.6 & 20.0 & 17.4 & 9.1 & 11.3 & 10.6 & 9.8 \\
\hline $\mathrm{MCPCH}$ & 23.7 & 32.5 & 41.3 & 28.1 & 14.7 & 26.5 & 17.4 & 23.2 & 22.9 & 14.0 \\
\hline $\mathrm{HCH}$ & 5.8 & 4.7 & 3.3 & 13.2 & 12.3 & 17.1 & 8.0 & 14.3 & 12.1 & 13.1 \\
\hline
\end{tabular}

$463{ }^{\mathrm{a}} \mathrm{HDN}$ selectivity data taken from [3].

464 For comparison purposes, the $\mathrm{HDN}$ selectivity of a sulfided $\mathrm{Ni}-\mathrm{Mo} / \mathrm{Al}_{2} \mathrm{O}_{3}$ catalyst tested under the 465 identical reaction conditions is also provided in Table 4 [3]. Four hydrocarbon products associated 466 with the HYD pathway for N removal - cyclohexylbenzene $(\mathrm{CHB})$, bicyclohexane $(\mathrm{BCH}),(2-$ 467 methylcyclopentyl)cyclohexane $(\mathrm{MCPCH})$, and hexylcyclohexane $(\mathrm{HCH})$ - were observed in 468 significant quantities for the supported $\mathrm{Ni}_{2} \mathrm{P}$ and sulfided $\mathrm{Ni}-\mathrm{Mo} / \mathrm{Al}_{2} \mathrm{O}_{3}$ catalysts. There are 469 important differences in product selectivities, with the $\mathrm{Ni}_{2} \mathrm{P}$ catalysts, regardless of support or 470 preparation method, producing substantially more of the partially hydrogenated product CHB and 471 less of the fully hydrogenated product $\mathrm{BCH}$ than the sulfided $\mathrm{Ni}-\mathrm{Mo} / \mathrm{Al}_{2} \mathrm{O}_{3}$ catalyst. Across 472 supports, the $\mathrm{Ni}_{2} \mathrm{P} / \mathrm{ASA}$ catalysts generally produced the most $\mathrm{CHB}$, while the $\mathrm{Ni}_{2} \mathrm{P} / \mathrm{SiO}_{2}$ catalysts 473 produced the most MCPCH. 3.4 In situ preparation with $\mathrm{H}_{2} \mathrm{~S} / \mathrm{H}_{2}$

While the in situ preparation of supported $\mathrm{Ni}_{2} \mathrm{P}$ catalysts was carried out in $\mathrm{H}_{2}$, the use of a 3 mol\% $\mathrm{H}_{2} \mathrm{~S} / \mathrm{H}_{2}$ mixture for this purpose was also investigated for $\mathrm{Ni}_{2} \mathrm{P} / \mathrm{SiO}_{2}$. Compared in Figure $9 \mathrm{a}$

477 are the carbazole $\mathrm{HDN}$ conversions vs. temperature for $\mathrm{Ni}_{2} \mathrm{P} / \mathrm{SiO}_{2}$ catalysts prepared in situ using 
in $\mathrm{H}_{2} \mathrm{~S} / \mathrm{H}_{2}$ at $650 \mathrm{~K}$. The $\mathrm{Ni}_{2} \mathrm{P} / \mathrm{SiO}_{2}$ catalyst prepared from a hypophosphite-based precursor using $\mathrm{H}_{2} \mathrm{~S} / \mathrm{H}_{2}$ exhibited high HDN activity, with carbazole HDN conversions (623-673 K) about 5\% less than those of the same precursor treated in situ in $\mathrm{H}_{2}$. Importantly, the $\mathrm{Ni}_{2} \mathrm{P} / \mathrm{SiO}_{2}$ catalyst had $\mathrm{HDN}$ conversions $3-5 \%$ higher than the sulfided $\mathrm{Ni}-\mathrm{Mo} / \mathrm{Al}_{2} \mathrm{O}_{3}$ catalyst prepared using the identical pretreatment in $\mathrm{H}_{2} \mathrm{~S} / \mathrm{H}_{2}$ at $650 \mathrm{~K}$. XRD patterns acquired after $\mathrm{HDN} / \mathrm{HDS}$ testing for the $\mathrm{Ni}_{2} \mathrm{P} / \mathrm{SiO}_{2}$ catalysts prepared in situ in $\mathrm{H}_{2}$ or $\mathrm{H}_{2} \mathrm{~S} / \mathrm{H}_{2}$ are shown in Figure $9 \mathrm{~b}$. In both cases, phase pure $\mathrm{Ni}_{2} \mathrm{P}$ was observed, providing strong evidence for the successful synthesis of $\mathrm{Ni}_{2} \mathrm{P}$ on the $\mathrm{SiO}_{2}$ support using either $\mathrm{H}_{2}$ or $\mathrm{H}_{2} \mathrm{~S} / \mathrm{H}_{2}$, as well as for the stability of the $\mathrm{Ni}_{2} \mathrm{P}$ catalysts during HDN/HDS testing. The average $\mathrm{Ni}_{2} \mathrm{P}$ crystallite sizes are indicated on the XRD patterns, the larger $\mathrm{Ni}_{2} \mathrm{P}$ crystallite size for the $\mathrm{Ni}_{2} \mathrm{P} / \mathrm{SiO}_{2}$ catalyst prepared in $\mathrm{H}_{2} \mathrm{~S} / \mathrm{H}_{2}$ is likely responsible for the lower $\mathrm{HDN}$ activity of this catalyst relative to the $\mathrm{Ni}_{2} \mathrm{P} / \mathrm{SiO}_{2}$ catalyst prepared in $\mathrm{H}_{2}$.

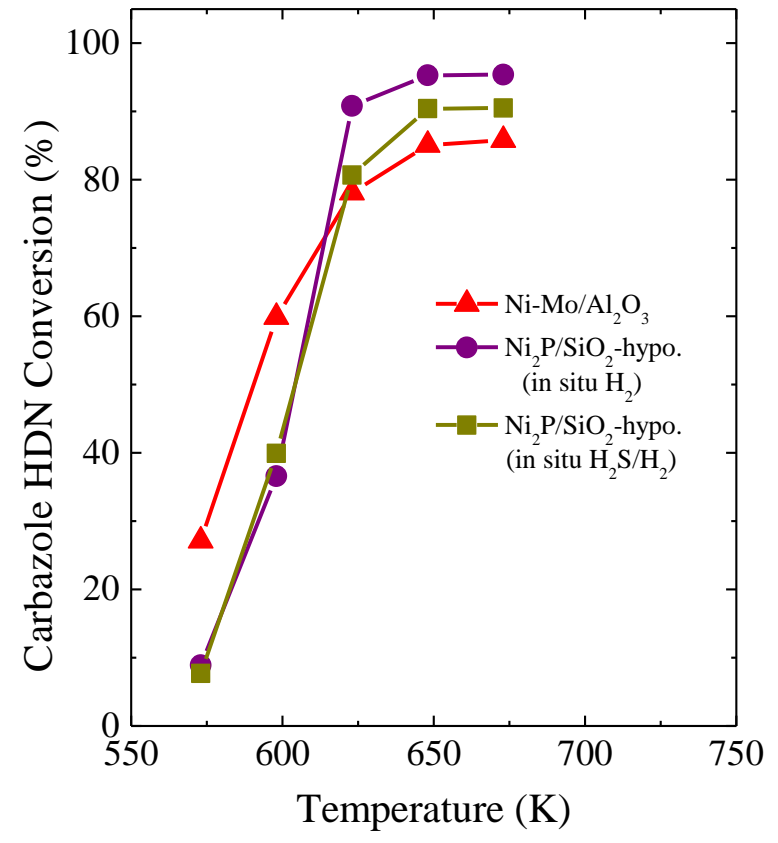

(a)

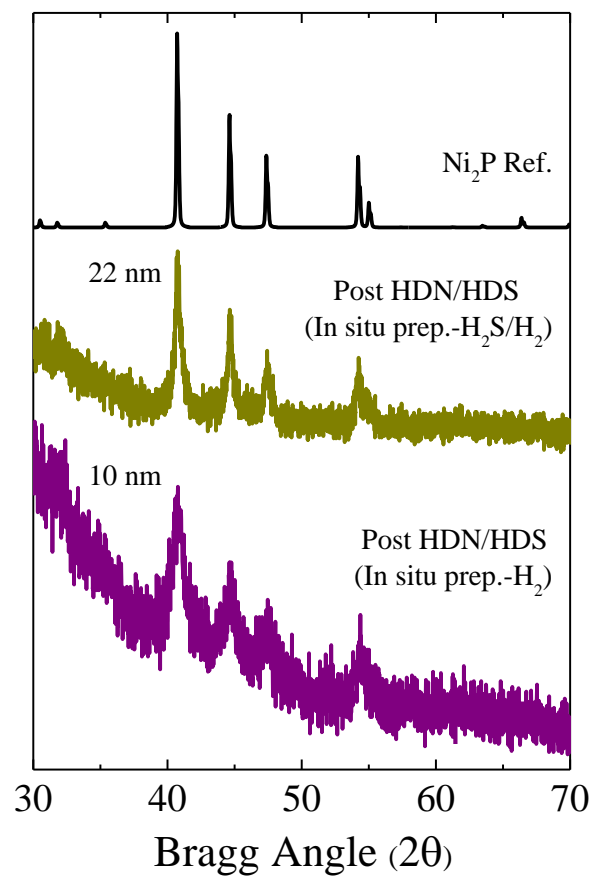

(b)

Figure 9: (a) Carbazole $\mathrm{HDN}$ conversion vs. temperature for $\mathrm{Ni}_{2} \mathrm{P} / \mathrm{SiO}_{2}$ catalysts prepared in situ using $\mathrm{H}_{2}$ or $\mathrm{H}_{2} \mathrm{~S} / \mathrm{H}_{2}$. HDN conversion data for the $\mathrm{Ni}-\mathrm{Mo} / \mathrm{Al}_{2} \mathrm{O}_{3}$ catalyst taken from [3]. (b) XRD patterns acquired after $\mathrm{HDN} / \mathrm{HDS}$ testing for $\mathrm{Ni}_{2} \mathrm{P} / \mathrm{SiO}_{2}$ catalysts prepared in situ using $\mathrm{H}_{2}$ or $\mathrm{H}_{2} \mathrm{~S} / \mathrm{H}_{2}$. 


\section{DISCUSSION}

While metal phosphide catalysts have shown substantial promise for use in a new generation of hydrotreating catalysts, significant hurdles will need to be overcome before they can compete with well-established Co-Mo and Ni-Mo sulfide catalysts for use in industrial processing. These hurdles include too many synthetic steps (e.g. ex situ reduction, passivation and then in situ activation) and high TPR temperatures (> 673 K) used in the preparation of metal phosphide catalysts, and low HDN/HDS activities on supports other than $\mathrm{SiO}_{2}$. To address these issues, a lowtemperature synthesis of oxide-supported $\mathrm{Ni}_{2} \mathrm{P}$ has been developed that uses $\mathrm{Ni}(\mathrm{OH})_{2}$ and $\mathrm{H}_{3} \mathrm{PO}_{2}$ to prepare catalyst precursors consisting of $\mathrm{Ni}\left(\mathrm{H}_{2} \mathrm{PO}_{2}\right)_{2}$ supported on $\mathrm{SiO}_{2}, \gamma-\mathrm{Al}_{2} \mathrm{O}_{3}$ and $\mathrm{ASA}$, which are subsequently reduced in situ $(\leq 673 \mathrm{~K})$ using either $\mathrm{H}_{2}$ or $\mathrm{H}_{2} \mathrm{~S} / \mathrm{H}_{2}$ to yield highly active $\mathrm{Ni}_{2} \mathrm{P}$ catalysts. Importantly, washing steps to remove salt byproducts from the $\mathrm{Ni}_{2} \mathrm{P}$ catalysts are unnecessary when using the supported $\mathrm{Ni}\left(\mathrm{H}_{2} \mathrm{PO}_{2}\right)_{2}$ precursors.

Low temperature syntheses of $\mathrm{Ni}_{2} \mathrm{P}$ catalysts have been reported by others and these preparation methods have employed a number of strategies to lower the reduction temperature needed to convert the catalyst precursor into the active $\mathrm{Ni}_{2} \mathrm{P}$ phase. Syntheses have been reported that use $\mathrm{P}$ sources other than phosphate $\left(\mathrm{PH}_{3}\right.$ [20-22], $\mathrm{P}\left(\mathrm{C}_{6} \mathrm{H}_{5}\right)_{3}$ [23,24], $\mathrm{P}\left(\mathrm{C}_{8} \mathrm{H}_{17}\right)_{3}$ [25], $\mathrm{H}_{2} \mathrm{PO}_{2}^{-}$ $\left.[9,10,16,26,27], \mathrm{H}_{2} \mathrm{PO}_{3}{ }^{-}[6,7,28,29]\right)$, include small amounts of noble metals in the precursors [30], or utilize an $\mathrm{H}_{2}$ plasma [31]. Focusing on syntheses that use phosphorus oxoacids or their salts as the P source (and without the addition of noble metals), the maximum TPR temperature needed to reduce the catalyst precursors to $\mathrm{Ni}_{2} \mathrm{P}$ has been lowered from $\geq 873 \mathrm{~K}$ for phosphate-based precursors, to $673-823 \mathrm{~K}$ for phosphite-based precursors, and to $473-773 \mathrm{~K}$ for hypophosphitebased precursors [2]. The preparation of nickel phosphite $\left(\mathrm{Ni}\left(\mathrm{H}_{2} \mathrm{PO}_{3}\right)_{2}\right)$ based precursors via the stoichiometric reaction of $\mathrm{Ni}(\mathrm{OH})_{2}$ and phosphorus acid $\left(\mathrm{H}_{3} \mathrm{PO}_{3}\right)$ has been reported [6,7] and, while avoiding salt byproducts (e.g. $\mathrm{NaCl}$ ), the higher oxidation state of $\mathrm{P}$ in phosphite required a higher 
TPR temperature to successfully reduce the precursor to $\mathrm{Ni}_{2} \mathrm{P}$ than is needed for hypophosphitebased precursors.

The use of hypophosphite as the $\mathrm{P}$ source enables the reduction of precursors to $\mathrm{Ni}_{2} \mathrm{P}$ at low temperatures, but syntheses reported in the literature have utilized nickel salts $\left(\mathrm{NiCl}_{2} \bullet 6 \mathrm{H}_{2} \mathrm{O}\right.$, $\left.\mathrm{Ni}\left(\mathrm{NO}_{3}\right)_{2} \bullet 6 \mathrm{H}_{2} \mathrm{O}\right)$ and $\mathrm{P}$ salts $\left(\mathrm{NaH}_{2} \mathrm{PO}_{2}, \mathrm{NH}_{4} \mathrm{H}_{2} \mathrm{PO}_{2}\right)$ to prepare unsupported or supported $\mathrm{Ni}\left(\mathrm{H}_{2} \mathrm{PO}_{2}\right)_{2}$ precursors $[9,10,16,26,27]$. As a result, the salt byproducts formed during synthesis, and which remain on the catalysts after reduction, must be removed by an $\mathrm{H}_{2} \mathrm{O}$ washing step to obtain high activity $\mathrm{Ni}_{2} \mathrm{P}$ catalysts. By employing the reaction between $\mathrm{Ni}(\mathrm{OH})_{2}$ and $\mathrm{H}_{3} \mathrm{PO}_{2}$ to prepare $\mathrm{Ni}\left(\mathrm{H}_{2} \mathrm{PO}_{2}\right)_{2}$ precursors, in an analogous fashion as was done for $\mathrm{Ni}\left(\mathrm{H}_{2} \mathrm{PO}_{3}\right)_{2}$, the need for a washing step is eliminated and the precursors can be used for in situ preparation of $\mathrm{Ni}_{2} \mathrm{P}$ catalysts at $673 \mathrm{~K}$.

The TPR-MS traces for the reference compound $\mathrm{NaH}_{2} \mathrm{PO}_{2}$ in $\mathrm{Ar}$ and $10 \mathrm{~mol} \% \mathrm{H}_{2} / \mathrm{Ar}$ (Figure 1) reveal that the decomposition/reaction of hypophosphite is a multi-step process. A proposed set of reactions for the decomposition $\mathrm{NaH}_{2} \mathrm{PO}_{2}$ in $\mathrm{Ar}$ (Equations 1-2) involves the sequential disproportionation of $\mathrm{NaH}_{2} \mathrm{PO}_{2}$ and $\mathrm{Na}_{2} \mathrm{HPO}_{3}$ to give $\mathrm{PH}_{3}$ as a gaseous product and, in the case of the second reaction, also produces $\mathrm{H}_{2} \mathrm{O}$. The evolution of $\mathrm{PH}_{3}$ in peaks at 535 and $579 \mathrm{~K}$ from the decomposition of $\mathrm{NaH}_{2} \mathrm{PO}_{2}$ is consistent with $\mathrm{PH}_{3}$ being the reactant for conversion of $\mathrm{Ni}^{2+}\left(\mathrm{NiCl}_{2}\right.$, $\left.\mathrm{Ni}\left(\mathrm{NO}_{3}\right)_{2}, \mathrm{NiO}, \mathrm{NiS}\right)$ to $\mathrm{Ni}_{2} \mathrm{P}$ when hyphophosphite-based precursors are heated to $\sim 623 \mathrm{~K}$ or higher in inert gas $\left(\mathrm{Ar}, \mathrm{N}_{2}\right)[10,16,27]$. Phosphine, in the form of $10 \mathrm{~mol} \% \mathrm{PH}_{3} / \mathrm{H}_{2}$ or $20 \mathrm{~mol} \% \mathrm{PH}_{3} / \mathrm{He}$, has been used directly for the conversion of supported $\mathrm{Ni}$ and $\mathrm{NiO}$ to $\mathrm{Ni}_{2} \mathrm{P}$ [20-22], but the toxicity and difficulty in handling of $\mathrm{PH}_{3}$ make its direct use as a reagent in catalyst synthesis impractical. While the use of hypophosphite salts in preparing $\mathrm{Ni}_{2} \mathrm{P}$ catalysts obviates the need to use $\mathrm{PH}_{3}$ directly, an $\mathrm{H}_{2} \mathrm{O}$ washing step is necessary to remove salt byproducts formed during $\mathrm{Ni}_{2} \mathrm{P}$ synthesis [2]. 
The TPR-MS traces for unsupported and supported $\mathrm{Ni}\left(\mathrm{H}_{2} \mathrm{PO}_{2}\right)_{2}$ precursors (Figures 2-3), with the $\mathrm{Ni}\left(\mathrm{H}_{2} \mathrm{PO}_{2}\right)_{2}$ prepared using $\mathrm{Ni}(\mathrm{OH})_{2}$ and $\mathrm{H}_{3} \mathrm{PO}_{2}$, indicate $\mathrm{Ni}_{2} \mathrm{P}$ is formed in the temperature range 468-561 K. The temperature at which $\mathrm{Ni}\left(\mathrm{H}_{2} \mathrm{PO}_{2}\right)_{2}$ reacts varies from $468 \mathrm{~K}$ for unsupported $\mathrm{Ni}\left(\mathrm{H}_{2} \mathrm{PO}_{2}\right)_{2}$ to progressively higher temperatures for $\mathrm{Ni}\left(\mathrm{H}_{2} \mathrm{PO}_{2}\right)_{2}$ supported on $\mathrm{SiO}_{2}(476$ and 497 $\mathrm{K}), \gamma-\mathrm{Al}_{2} \mathrm{O}_{3}(507 \mathrm{~K})$ and ASA $(561 \mathrm{~K})$. The relative amount of $\mathrm{PH}_{3}$ evolved decreases in the order $\mathrm{SiO}_{2}>\gamma-\mathrm{Al}_{2} \mathrm{O}_{3}>\mathrm{ASA}$, which when combined with the increasing reaction temperatures, indicates that the extent of interaction of impregnated $\mathrm{P}$ with the supports increases in the order: $\mathrm{SiO}_{2}<\gamma-$ $\mathrm{Al}_{2} \mathrm{O}_{3}<$ ASA. These observations are consistent with the preparation of $\mathrm{Ni}_{2} \mathrm{P}$ on the three supports using phosphate, as progressively more $\mathrm{P}$ was needed in the order: $\mathrm{SiO}_{2}(\mathrm{P} / \mathrm{Ni}=0.9), \gamma-\mathrm{Al}_{2} \mathrm{O}_{3}(\mathrm{P} / \mathrm{Ni}$ $=1.5)$, ASA $(\mathrm{P} / \mathrm{Ni}=2.2)$ to obtain phase-pure $\mathrm{Ni}_{2} \mathrm{P}$. The phosphate-based precursors were not calcined in order to minimize potential reactions with the support (e.g. formation of $\mathrm{AlPO}_{4}[5]$ ), but a TPR temperature of $923 \mathrm{~K}$ was needed to form phase-pure $\mathrm{Ni}_{2} \mathrm{P}$ on the three supports. The average $\mathrm{Ni}_{2} \mathrm{P}$ crystallite sizes determined by XRD (Figure 4 and Table 1) were substantially smaller for the $\mathrm{Ni}_{2} \mathrm{P}$ catalysts prepared using hypohosphite-based precursors compared to phosphate-based tested catalysts (prepared in situ and ex situ) were highly enriched in P relative to the nominal bulk and measured surface compositions of the hypophosphite-based precursors (Table 2). The XPS spectra acquired after $\mathrm{HDS} / \mathrm{HDN}$ testing of in situ prepared $\mathrm{Ni}_{2} \mathrm{P} / \mathrm{SiO}_{2}$ and $\mathrm{Ni}_{2} \mathrm{P} / \mathrm{Al}_{2} \mathrm{O}_{3}$ catalysts (Figure 6) show the surface $\mathrm{P}$ to be almost exclusively $\mathrm{P}^{5+}$ species in the form of phosphate. While passivation of the HDS/HDN-tested catalysts in $1 \mathrm{~mol} \% \mathrm{O}_{2} / \mathrm{He}$ forms an oxidized surface layer on the $\mathrm{Ni}_{2} \mathrm{P}$ particles, the extent of surface enrichment of $\mathrm{P}$ in the form of phosphate is substantially 
higher than reported previously for phosphate-based $\mathrm{Ni}_{2} \mathrm{P} / \mathrm{SiO}_{2}$ and $\mathrm{Ni}_{2} \mathrm{P} / \mathrm{Al}_{2} \mathrm{O}_{3}$ catalysts [5]. The reaction proposed for the conversion of $\mathrm{Ni}\left(\mathrm{H}_{2} \mathrm{PO}_{2}\right)_{2}$ to $\mathrm{Ni}_{2} \mathrm{P}$ (Equation 5) yields $\mathrm{H}_{3} \mathrm{PO}_{4}$ as a product, and the XPS results suggest that some of this P remains on the catalyst surface as unreduced $\mathrm{H}_{\mathrm{x}} \mathrm{PO}_{4}{ }^{(3-\mathrm{x})-}$ species. The extent of surface $\mathrm{P}$ enrichment was observed to increase for the HDS/HDN-tested $\mathrm{Ni}_{2} \mathrm{P} / \mathrm{SiO}_{2}$ and $\mathrm{Ni}_{2} \mathrm{P} / \mathrm{Al}_{2} \mathrm{O}_{3}$ catalysts relative to the ex-situ prepared catalysts. The fact that no significant catalyst deactivation was observed suggests that this high surface $\mathrm{P}$ concentration does not have a deleterious effect on catalytic properties. Surface enrichment of P has been observed previously by XPS of unsupported $\mathrm{Ni}_{2} \mathrm{P}$ and $\mathrm{Co}_{\mathrm{x}} \mathrm{Ni}_{2} \mathrm{P}$ catalysts, and on the basis of acidity measurements carried out using n-propylamine, these surface $\mathrm{P}$ species were assigned to $\mathrm{H}_{\mathrm{X}} \mathrm{PO}_{4}{ }^{(3-\mathrm{x})-}$ [32]. The most active $\mathrm{Co}_{\mathrm{x}} \mathrm{Ni}_{2} \mathrm{P}$ for HDS of 4,6-dimethyldibenzothiophene, $\mathrm{Co}_{0.08} \mathrm{Ni}_{2} \mathrm{P}$, had the highest surface P enrichment and Brönsted acid site density, but also the lowest CO chemisorption capacity [32]. As described earlier, $\mathrm{H}_{3} \mathrm{PO}_{4}$ was identified as the P-containing byproduct formed during the reduction of unsupported $\mathrm{Ni}\left(\mathrm{H}_{2} \mathrm{PO}_{2}\right)_{2}$ and it is expected to remain adsorbed on the surface of the catalyst particles as $\mathrm{H}_{\mathrm{x}} \mathrm{PO}_{4}{ }^{(3-\mathrm{x})-}$ species following in situ preparation. The enrichment of $\mathrm{Ni}_{2} \mathrm{P}$ particle surfaces with $\mathrm{H}_{\mathrm{x}} \mathrm{PO}_{4}{ }^{(3-\mathrm{x})-}$ species could also explain why the $\mathrm{Ni}_{2} \mathrm{P} / \mathrm{SiO}_{2}$ and $\mathrm{Ni}_{2} \mathrm{P}_{/} \mathrm{Al}_{2} \mathrm{O}_{3}$ catalysts prepared from hypophosphite-based precursors have similar or lower $\mathrm{CO}$ chemisorption capacities than the catalysts prepared from phosphate-based precursors (Table 1), despite the hypophosphite-based $\mathrm{Ni}_{2} \mathrm{P}$ catalysts having significantly smaller average $\mathrm{Ni}_{2} \mathrm{P}$ crystallite sizes. The $\mathrm{CO}$ chemisorption capacities of the $\mathrm{Ni}_{2} \mathrm{P} / \mathrm{ASA}$ catalysts do not follow the same pattern, but this could be due to the large excess of P needed to prepare the phosphate-based $\mathrm{Ni}_{2} \mathrm{P}$ catalyst on ASA, resulting in an anomalously low $\mathrm{CO}$ chemisorption capacity in this case.

The $\mathrm{Ni}_{2} \mathrm{P}$ catalysts prepared in situ from hypophosphite-based precursors had the highest HDS/HDN conversions and TOFs for the different preparation methods on the $\gamma-\mathrm{Al}_{2} \mathrm{O}_{3}$ and ASA supports. For $\mathrm{SiO}_{2}$, the catalyst prepared in situ from hypophosphite had similar HDN/HDS 
conversions as did a phosphate-based catalyst reported previously [3], but had significantly higher TOFs. The phosphate-based $\mathrm{Ni}_{2} \mathrm{P} / \mathrm{SiO}_{2}$ catalyst had a higher $\mathrm{Ni}_{2} \mathrm{P}$ loading $(25 \mathrm{wt} \%$ ) than did the hypophosphite-based $\mathrm{Ni}_{2} \mathrm{P} / \mathrm{SiO}_{2}$ catalyst (15 wt $\%$ ), so the most useful comparison of HDN/HDS activities is the TOFs in this case. For each support, the in situ prepared $\mathrm{Ni}_{2} \mathrm{P}$ catalysts significantly outperformed the ex situ prepared $\mathrm{Ni}_{2} \mathrm{P}$ catalysts; the disparity is most clearly seen for the $\mathrm{Ni}_{2} \mathrm{P} / \mathrm{Al}_{2} \mathrm{O}_{3}$ and $\mathrm{Ni}_{2} \mathrm{P} / \mathrm{ASA}$ catalysts for which the hypophosphite-based precursors reduced in situ had carbazole HDN conversion 2-3 times higher than the same precursors reduced ex situ and then activated in the reactor. These results highlight the importance of a preparation method that allows low temperature synthesis of the active $\mathrm{Ni}_{2} \mathrm{P}$ catalyst directly in the hydrotreating reactor. Finally, the in situ prepared $\mathrm{Ni}_{2} \mathrm{P} / \mathrm{SiO}_{2}$ and $\mathrm{Ni}_{2} \mathrm{P} / \mathrm{Al}_{2} \mathrm{O}_{3}$ catalysts had higher HDN/HDS TOFs than did a commercial Ni-Mo/ $/ \mathrm{Al}_{2} \mathrm{O}_{3}$ catalyst, and the high activity of a $\mathrm{Ni}_{2} \mathrm{P} / \mathrm{SiO}_{2}$ catalyst could be achieved using $\mathrm{H}_{2} \mathrm{~S} / \mathrm{H}_{2}$ to convert the $\mathrm{Ni}\left(\mathrm{H}_{2} \mathrm{PO}_{2}\right)_{2}$ precursor to phase-pure $\mathrm{Ni}_{2} \mathrm{P}$ on the support. The ability to use $\mathrm{H}_{2} \mathrm{~S} / \mathrm{H}_{2}$ for in situ preparation of $\mathrm{Ni}_{2} \mathrm{P}$ catalysts at low temperatures may prove to be a particularly attractive feature of the catalyst preparation method described herein as it would enable a $\mathrm{Ni}_{2} \mathrm{P}$-based catalyst to be prepared from a hypophosphite-based precursor in the same catalyst bed as a conventional Co-Mo or Ni-Mo sulfide catalyst.

The most highly active $\mathrm{Ni}_{2} \mathrm{P}$ catalysts identified in this study, in situ prepared $\mathrm{Ni}_{2} \mathrm{P} / \mathrm{SiO}_{2}$ and $\mathrm{Ni}_{2} \mathrm{P} / \mathrm{Al}_{2} \mathrm{O}_{3}$, had favorable product selectivities relative to a commercial $\mathrm{Ni}-\mathrm{Mo} / \mathrm{Al}_{2} \mathrm{O}_{3}$ catalyst. The $\mathrm{Ni}_{2} \mathrm{P}$ catalysts produced nearly three times more of the partially hydrogenated hydrocarbon $\mathrm{CHB}$ than did the $\mathrm{Ni}-\mathrm{Mo} / \mathrm{Al}_{2} \mathrm{O}_{3}$ catalyst, while the sulfide catalyst produced substantially more of the fully hydrogenated hydrocarbon $\mathrm{BCH}$ (Table 4). This product selectivity difference is important as it indicates a lower demand for $\mathrm{H}_{2}$ for the $\mathrm{Ni}_{2} \mathrm{P}$ catalysts while maintaining high HDN (and HDS) conversion.

\section{CONCLUSIONS}


613 hypophosphite-based precursors formed by the reaction of $\mathrm{Ni}(\mathrm{OH})_{2}$ and $\mathrm{H}_{3} \mathrm{PO}_{2}$ yields highly active 614 catalysts for HDN and HDS of a mixed carbazole/benzothiophene feed. TPR-MS measurements 615 reveal the reaction of $\mathrm{Ni}\left(\mathrm{H}_{2} \mathrm{PO}_{2}\right)_{2}$ to form $\mathrm{Ni}_{2} \mathrm{P}$ occurs at 468-561 K, with unsupported $\mathrm{Ni}\left(\mathrm{H}_{2} \mathrm{PO}_{2}\right)_{2}$ 616 reacting at the low end of this temperature range and $\mathrm{Ni}\left(\mathrm{H}_{2} \mathrm{PO}_{2}\right)_{2}$ on the Al-containing supports 617 reacting at the high end of this range. The surface compositions of the ex situ prepared catalysts 618 and of HDN/HDS-tested catalysts are highly enriched in $\mathrm{P}$, with much of this surface $\mathrm{P}$ in the form 619 of $\mathrm{H}_{\mathrm{x}} \mathrm{PO}_{4}{ }^{(3-\mathrm{x})-}$ species. In situ prepared $\mathrm{Ni}_{2} \mathrm{P} / \mathrm{SiO}_{2}$ and $\mathrm{Ni}_{2} \mathrm{P}_{\mathrm{A}} \mathrm{Al}_{2} \mathrm{O}_{3}$ catalysts had higher TOFs than 620 did a commercial $\mathrm{Ni}-\mathrm{Mo} / \mathrm{Al}_{2} \mathrm{O}_{3}$ catalyst, and high catalytic activity could be achieved using $\mathrm{H}_{2} \mathrm{~S} / \mathrm{H}_{2}$ 621 for the in situ conversion of the $\mathrm{Ni}\left(\mathrm{H}_{2} \mathrm{PO}_{2}\right)_{2}$ precursor to phase-pure $\mathrm{Ni}_{2} \mathrm{P}$.

622

\section{ACKNOWLEDGEMENTS}

This research was supported by a grant from Shell Global Solutions (U.S.) Inc. as well as by the National Science Foundation under grant number CHE-1361702. The authors acknowledge the assistance of Dr. Randall Yeates (Shell Oil Co.) for his assistance with the XPS measurements of

627 the HDN/HDS-tested catalysts. The authors acknowledge Arda Genc and Huikai Cheng (FEI Co.) 628 and Catherine Miles (WWU) for acquisition and analysis of the TEM and EDX data. 


\section{REFERENCES}

631

632

633

634

635

636

637

638

639

640

641

642

643

644

645

646

647

648

649

650

651

652

653

654

655

656

657

658

659

660

661

662

663

664

665

666

667

668

669

670

671

672

673

674

675

676

1. S.T. Oyama, T. Gott, H. Zhao, Y.-K. Lee, Catal. Today, 143 (2009) 94-107.

2. R. Prins, M.E. Bussell, Catal. Lett., 142 (2012) 1413-1436.

3. R.H. Bowker, B.A. Carrillo, B. Illic, M.A. Reynolds, B.D. Murray, M.E. Bussell, Appl. Catal. A, 482 (2014) 221-230.

4. S. Soled, S. Miseo, J. Baumgartner, J. Guzman, T. Bolin, R. Meyer, Catal. Today, 246 (2015) 38 .

5. S.J. Sawhill, K.A. Layman, D.R. Van Wyk, M.H. Engelhard, C. Wang, M.E. Bussell, J. Catal., 231 (2005) 300-313.

6. J.A. Cecilia, A. Infantes-Molina, E. Rodríguez-Castellón, A. Jiménez-López, J. Catal., 263 (2009) 4-15.

7. J.A. Cecilia, A. Infantes-Molina, E. Rodríguez-Castellón, A. Jiménez-López, J. Phys. Chem. C, 113 (2009) 17032-17044.

8. J. Cecilia, A. Infantes-Molina, E. Rodríguez-Castellón, A. Jiménez-López, Appl. Catal. B., 92 (2009) 100-113.

9. Q. Guan, W. Li, M. Zhang, K. Tao, J. Catal., 263 (2009) 1-3.

10. Q. Guan, W. Li, J. Catal., 271 (2010) 413-415.

11. Q. Guan, X. Cheng, R. Li, W. Li, J. Catal., 299 (2013) 1-9.

12. C. Rammelsberg, Journal of the Chemical Society, 26 (1873) 1-12.

13. L.S. Mayants, E.I. Matrosov, Inorganic Materials, 1 (1965) 499-505.

14. N.C. Johnson, W.E. Bull, Inorg. Chim. Acta, 27 (1978) 191-195.

15. J.-C. Merlin, Bull. Soc. Chim. Fr., (1955) 927-930.

16. H. Song, M. Dai, H. Song, X. Wan, X. Xu, Appl. Catal. A, 462-463 (2013) 247-255.

17. J.A. Rodriguez, J.-Y. Kim, J.C. Hanson, S.J. Sawhill, M.E. Bussell, J. Phys. Chem. B, 107 (2003) 6276-6285.

18. JCPDS Powder Diffraction File, International Centre for Diffraction Data, Swarthmore, PA, 2000.

19. S.J. Sawhill, D.C. Phillips, M.E. Bussell, J. Catal., 215 (2003) 208-219. 
20. S. Yang, R. Prins, Chem. Commun., (2005) 4178-4180.

21. S. Yang, C. Liang, R. Prins, J. Catal., 237 (2006) 118-130.

22. E.L. Muetterties, J.C. Sauer, J. Am. Chem. Soc., 96 (1974) 3410-3415.

23. Z. Wang, L. Zhou, M. Zhang, W. Li, K. Tao, Chemistry - An Asian Journal, 4 (2009) 17941797.

24. J. Wang, H. Chen, Y. Fu, J. Shen, Appl. Catal. B., 160-161 (2014) 344-355.

25. G.H.L. Savithra, R.H. Bowker, B.A. Carrillo, M.E. Bussell, S.L. Brock, Chem. Mater., 25 (2013) 825-833.

26. G. Shi, J. Shen, J. Mater. Chem., 19 (2009) 2295-2297.

27. L. Song, S. Zhang, X. Wu, Y. Li, Vacuum, 111 (2015) 68-72.

28. P. Bui, J.A. Cecilia, S.T. Oyama, A. Infantes-Molina, H. Zhao, D. Li, E. Rodriguez-Castellón, A. Jiménez-López, J. Catal., 294 (2012) 184-198.

29. J.A. Cecilia, A. Infantes-Molina, E. Rodriguez-Castellon, A. Jimenez-Lopez, S.T. Oyama, Appl. Catal. B., 136-137 (2013) 140-149.

30. V. Teixeira da Silva, L.A. Sousa, R.M. Amorim, L. Andrini, S.J.A. Figueroa, F.G. Requejo, F.C. Vincentini, J. Catal., 279 (2011) 88-102.

31. A. Wang, M. Qin, J. Guan, L. Wang, H. Guo, X. Li, Y. Wang, R. Prins, Y. Hu, Angew. Chem. Int. Ed., 47 (2008) 6052-6054.

32. I.I. Abu, K.J. Smith, J. Catal., 241 (2006) 356-366. 


\section{GRAPHICAL ABSTRACT}
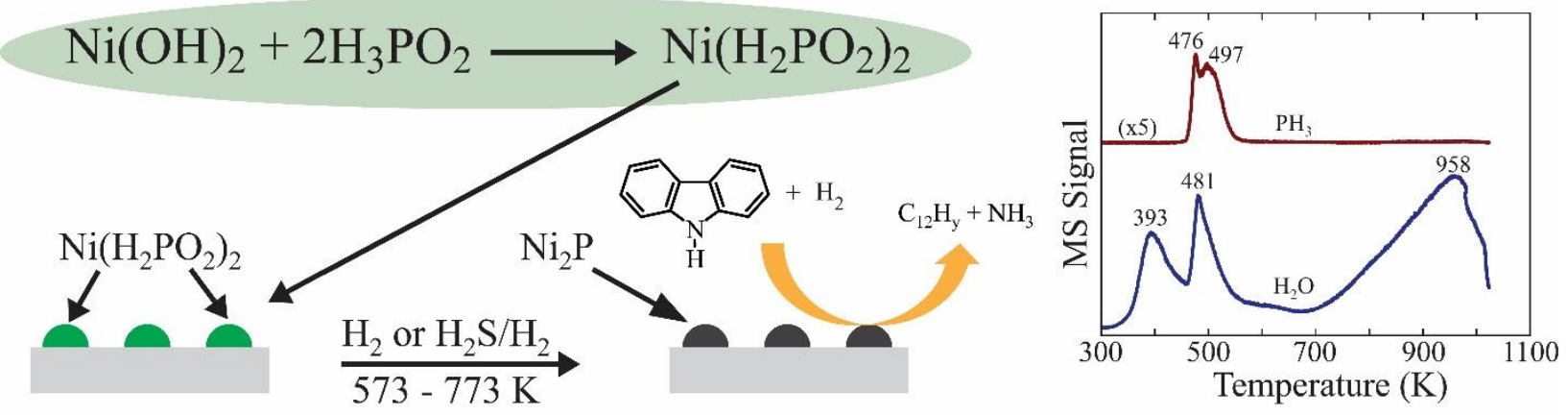